\title{
Offshoring and Skill-upgrading in French Manufacturing*
}

\author{
Juan Carluccio ${ }^{\dagger} \quad$ Alejandro Cuñat ${ }^{\ddagger}$ Harald Fadinger ${ }^{\S} \quad$ Christian Fons-Rosen $₫$
}

October 2018

\begin{abstract}
Using French manufacturing firm-level data for the years 1996 -2007, we uncover a novel set of stylized facts about offshoring behavior: (i) Low-productivity firms ("non-importers") obtain most of their inputs domestically. (ii) Medium-productivity firms offshore skill-intensive inputs to skill-abundant countries and are more labor intensive in their domestic production than non-importers. (iii) Higher-productivity firms additionally offshore labor-intensive inputs to labor-abundant countries and are more skill intensive than non-importers. We develop a model in which heterogeneous firms, subject to fixed costs, can offshore intermediate inputs of different skill intensities to countries with different skill abundance. This leads to endogenous within-industry variation in domestic skill intensities. We provide econometric evidence supporting the factor-proportions channel through which reductions in offshoring costs to labor-abundant countries have significantly increased firm-level skill intensities of French manufacturers.
\end{abstract}

KEYWORDS: offshoring, heterogeneous firms, firm-level factor intensities, skill upgrading Heckscher-Ohlin.

JEL CLASSIFICATION: F11, F12, F14

\footnotetext{
${ }^{*}$ We are grateful to Gene Grossman and Marc Melitz for detailed comments and to numerous seminar participants at Banque de France, Bayreuth, Bergen, Copenhagen Business School, Central European University, CREI, ECARES, Essex, LSE, IIES, Humboldt, Innsbruck, Mannheim, Munich, Murcia, Passau, Southampton, Surrey, Vienna, the CES-ifo Delphi Conference, the Barcelona GSE Summer Institute, the IVIE Workshop on Trade and Growth, the CES-ifo Venice Summer Institute, the FIW conference and the TRISTAN workshop for helpful comments. This work is supported by a public grant overseen by the French National Research Agency (ANR) as part of the "Investissements d'avenir" program (reference: ANR-10-EQPX-17 - Centre d'accès sécurisé aux données CASD). Cuñat gratefully acknowledges financial support by the Austrian Science Fund (FWF \#AP23424-G11) and the hospitality of CREI while revising this paper. Fadinger gratefully acknowledges financial support by DFG (Firm-level models of international trade). Fons-Rosen gratefully acknowledges financial support by the Spanish Ministry of Economy and Competitiveness (ECO2014-55555-P). A previous version appeared as CEPR Discussion Paper Nr. 10864.

${ }^{\dagger}$ Banque de France and University of Surrey. Email: juan.carluccio@gmail.com.

${ }^{\ddagger}$ University of Vienna and CES-ifo. Email: alejandro.cunat@univie.ac.at.

${ }^{\S}$ University of Mannheim and CEPR. Corresponding author. Adress: Department of Economics, University of Mannheim, L7 3-5, D-68163 Mannheim, Germany. Email: harald.fadinger@uni-mannheim.de.

`UC Merced. Email: cfons-rosen@ucmerced.edu
} 


\section{Introduction}

Over the last decades, international trade has become an important determinant of labor-market outcomes in rich countries. A recent empirical literature (e.g., Autor et al., 2013) has produced convincing evidence suggesting that trade with poor (skilled-labor scarce) countries affects workers in rich countries in a sizable way. In general, these effects exacerbate differences between skilled and unskilled workers in many dimensions, such as wages, and unemployment (Autor et al., 2014, Hummels et al., 2014). This paper deepens our understanding of the specific channels through which international trade contributes to changes in the relative demand for skilled workers in industrialized countries.

In particular, we focus on how the offshoring of intermediate inputs by French manufacturing firms affects the employment of skilled workers relative to unskilled workers in their French plants. We uncover the following set of novel empirical facts: (i) Low-productivity firms obtain their inputs domestically and display litte variation in their domestic skill intensity in comparison with offshoring firms. (ii) Medium-productivity firms offshore the production of skill-intensive inputs to skill-abundant locations and are more labor intensive than low-productivity firms in their domestic production. (iii) High-productivity firms additionally import labor-intensive inputs from labor-abundant locations and are more skill intensive than non-importers. Moreover, the surge in imports from labor-abundant countries that has taken place between the mid-1990s and the mid-2000s has been accompanied by a sizable increase in the domestic skill intensity of French firms that import from these locations. The skill intensity of firms importing from skill-abundant countries has remained instead constant over this period.

Our empirical analysis is guided by a simple model with heterogeneous firms (Melitz, 2003) and trade in intermediate inputs. The latter differ in their relative factor intensities and source countries have relative factor prices inversely related to their factor abundance. Firms are heterogeneous in terms of productivity, and offshoring of intermediates requires the payment of per-input fixed offshoring costs. Firms must therefore weigh the reduction in their marginal costs resulting from offshoring, say, a labor-intensive input to a labor-abundant country against the fixed costs implied by such a decision. Higher firm-level productivity implies that a given cost reduction from offshoring yields larger gains in variable profits.

The model produces predictions consistent with the abovementioned patterns. From the perspective of a relatively skill-abundant country like France, low-productivity firms produce all inputs domestically, as their small size does not enable them to cover the fixed costs from off- 
shoring intermediates. Sufficiently productive firms offshore the most skill-intensive inputs to skill-abundant locations and labor-intensive inputs to labor-abundant locations. However, if offshoring costs are larger for labor-abundant locations, the productivity threshold for importing from these locations will be larger than the one for sourcing from skill-abundant locations. Imports from skill-abundant countries substitute for domestic skilled workers and thus reduce the domestic skill intensity of importers relative to that of non-importers. Symmetrically, imports from labor-abundant countries substitute for domestic unskilled employment, making domestic production more skill intensive. Thus, selection into offshoring generates endogenous withinindustry variation in skill intensities. Reductions in trade barriers vis-à-vis labor-abundant countries lead existing importers from these countries to source additional labor-intensive inputs and induce more firms to offshore to these countries. The domestic skill intensity of these firms will rise in comparison to that of firms not sourcing from labor-abundant countries.

Our focus on firms' importing decisions generates an additional number of testable predictions on their sourcing patterns. This allows us to gauge the microeconomic channels that determine firms' domestic relative factor-input choices.

(i) Within the subset of offshoring firms, the least productive among them only offshore the inputs with the most extreme intensities from countries with extreme factor ratios. This combination of inputs and locations are the ones that offer the largest cost savings from offshoring, which must compensate for the associated fixed costs. For the most productive firms, the fixed costs of offshoring are smaller relative to their revenues; therefore these firms will choose to also import inputs with less extreme factor intensities from countries with less extreme relative factor abundance. The mechanisms just described work on both sides of the skill-abundance spectrum.

(ii) The above prediction implies a connection between firms' imports and their domestic skill intensities: firms with larger imports from the set of labor-abundant countries have higher domestic skill intensities, while firms with larger imports from the set of skill-abundant countries feature lower skill intensities.

To test the empirical predictions of our model we use a quasi-exhaustive panel dataset of French manufacturing firms for the period 1996-2007. These data provide information on firmlevel imports by product and origin country, and have been extensively used in the literature due to their high quality (e.g. Berman, Martin, Mayer, 2012 and Mayer, Melitz, Ottaviano, 2014). We first confirm that prediction (i) on firms' sourcing patterns holds in the data. We then establish the link between firms' imports and their domestic skill intensity, as stated in (ii). We exploit supply shocks in France's trading partners to provide causal evidence that the surge in imports 
from labor-abundant countries has led to a substantial increase in French manufacturing firms' skill intensity over the sample period. In fact, we find that most of the observed within-firm changes in skill intensity can be explained by increased offshoring to labor-abundant countries. Importers from labor-abundant countries raised their average domestic skill intensity by $10 \%$. Our IV estimates imply that this number can be exclusively explained by increased offshoring to labor-abundant countries.

Our work has a clear connection to the Heckscher-Ohlin (HO) model. Traditional approaches here, based on the factor content of trade, have provided only limited empirical support (see, e.g, Bowen, Leamer, Sveikauskas, 1987; Trefler, 1995). By contrast, a more recent set of tests, based on disaggregate product level data, are highly supportive of factor proportions shaping countries' trade patterns (Romalis, 2004; Schott, 2004; Nunn, 2007). Our empirical evidence reinforces the latter approach by showing that the large within-industry variation in factor intensity we find in the data calls for using disaggregate product-level trade data when testing the HO mechanism. ${ }^{1}$

The paper also contributes to the recent literature on offshoring. In particular, our model is inspired by Feenstra and Hanson (1997), where firms offshore some of their labor-intensive activities in response to liberalization of capital markets, thereby reducing the demand for unskilled labor in the U.S. We extend their work by introducing firm heterogeneity, which enables us to derive and test implications at the firm level. Grossman and Rossi-Hansberg (2008) present an offshoring model with complementarities between domestically performed and offshored tasks where reductions in offshoring costs for unskilled tasks may benefit unskilled workers if complementarities are sufficiently strong to overturn standard HO forces. Our theory focuses instead on sourcing patterns and their implications for domestic firm-level skill intensities, for which we find strong empirical support: domestic skill intensities increase with imports from labor-abundant countries and decrease with imports from skill-abundant locations. ${ }^{2}$ In this regard, our work is also related to Yeaple (2003), who demonstrates that the structure of U.S. FDI reflects an interaction between country skilled-labor abundance and industry skilled-labor intensities that is consistent with comparative advantage.

There are several alternative explanations for the link between trade and the relative demand for skills that are consistent with two key features of the data: within-industry variation in skill

\footnotetext{
${ }^{1}$ Since the factor content literature requires the use of input-output tables to test the HO model and IO tables are typically available only at the 2-digit industry level, most of the heterogeneity in factor proportions across goods is lost.

${ }^{2}$ Gopinath and Neiman (2014) and Halpern et al. (2015) develop structural estimation methods for the productivity gains from importing, but remain silent on the distributional consequences of offshoring. Koren and Csillag (2011) provide empirical evidence for importing of skill-biased technologies.
} 
intensity and a positive correlation between skill intensity and productivity. However, all of them focus on the connection between exporting and domestic skill intensity. ${ }^{3}$ We emphasize instead the role of importing for skill upgrading and - while also controlling for the export channel in our empirical specifications - provide specific evidence for the corresponding theoretical mechanism. Specifically, we show that firms' sourcing patterns are in line with our model and that offshoring to labor-abundant countries increases domestic skill intensity, while offshoring to skill-abundant countries is associated with a decrease in this variable.

Finally, we also contribute to the empirical literature on importing and domestic factor demand using firm-level data. Hummels et al. (2014), for example, employ data on Danish importers and provide evidence that the wages of high-skilled workers are positively affected by offshoring. ${ }^{4}$ In contrast to this literature, which is purely empirical, we investigate the specific theoretical mechanisms through which skill demand at the firm level is affected by offshoring. Moreover, we show that the impact on the relative factor demand of firms depends on the factor abundance of the sourcing location.

The rest of the paper is structured as follows. In section 2, we set up our theoretical model and derive predictions on sourcing patterns and domestic skill intensity; section 3 describes the data; sections 4 and 5 report our empirical results; finally we present our conclusions in section 6.

\section{Model}

There are $N$ countries, denoted with $n=1,2, \ldots, N$, endowed with skilled labor ("skills") $H_{n}$ and unskilled labor ("labor") $L_{n}$, and ranked according to their relative skill abundance: $H_{1} / L_{1}<$ $\ldots<H_{N} / L_{N}$. Both production factors are supplied inelastically and are internationally immobile.

\footnotetext{
${ }^{3}$ Crozet and Trionfetti (2013) and Harrigan and Reshef (2015) construct HO models with exogenous withinsector heterogeneity in factor proportions. Burstein and Vogel (2016) use a hybrid Heckscher-Ohlin-Ricardo model with firm heterogeneity, where more productive firms are exogenously more skill intensive to study the impact of trade-cost reductions on the relative demand for skills. Several mechanisms to endogenize the connection between exports and the within-sector heterogeneity in skill intensities have been proposed. Helpman et al. (2010, 2015) develop assortative matching models, where more productive firms hire more skilled workers. In Verhoogen (2011) and Bustos (2012), trade liberalization induces more productive firms to self-select into quality upgrading and technology adoption, respectively. Ma et al. (2014) build on Bernard et al. (2011) and show that Chinese firms that start exporting expand the production of relatively labor-intensive products.

${ }^{4}$ Kramarz and Biscourp (2007) discover that imports of finished goods from low-wage countries are associated with lower employment growth of French firms. Mion and Zhu (2013), using data on Belgian firms, present evidence that import competition from China induces skill upgrading of the domestic workforce. Using French data, Carluccio et al. (2015) find that offshoring of finished goods increases the wages of managers but has no effect on the wages of blue-collar workers. Bloom et al. (2015) show that European firms exposed to Chinese imports invest more in $\mathrm{R} \& \mathrm{D}$ and engage in skill upgrading.
} 
Each country has a representative consumer with utility function $U_{n}=A_{n}^{\beta} C_{n}^{1-\beta}, \beta \in(0,1) . A_{n}$ represents consumption of a homogeneous numéraire good. $C_{n}$ denotes consumption of a DixitStiglitz aggregate of "manufacturing" varieties:

$$
C_{n}=\left[\int_{\omega \in \Omega} c_{n}(\omega)^{\frac{\sigma-1}{\sigma}} d \omega\right]^{\frac{\sigma}{\sigma-1}},
$$

$\sigma>1 . \Omega$ denotes the set of available varieties and $c_{n}(\omega)$ is the quantity of variety $\omega$ consumed by country $n$.

The numéraire-good industry, subject to perfect competition and free trade, uses technology $y_{n}=\left(h_{n} / \alpha\right)^{\alpha}\left(l_{n} /(1-\alpha)\right)^{1-\alpha}, \alpha \in(0,1) . h_{n}$ and $l_{n}$ denote, respectively, the skills and labor allocated to the numéraire industry in country $n$. In the manufacturing industry there is a given mass $M_{n}$ of producers per country. Each of them produces a different variety of the final good, over which it has monopoly power. Varieties are freely traded and are made with a continuum of inputs:

$$
q_{n}(\gamma)=\gamma\left[\int_{0}^{1} x_{n}(z)^{\frac{\varepsilon-1}{\varepsilon}} d z\right]^{\frac{\varepsilon}{\varepsilon-1}}
$$

where $\varepsilon>0$ denotes the elasticity of substitution between inputs. ${ }^{5} \gamma$ denotes a firm-specific productivity level, random and i.i.d. across firms. It is drawn from distribution $G(\gamma)$, which is identical across countries. $x_{n}(z)$ denotes the quantity of input $z \in[0,1]$ used in the production of a given final variety in country $n$. Any input for use in country $n$ can be produced in any country $n^{\prime} \in N$ according to

$$
y_{n^{\prime} n}(z)=\tau_{n^{\prime} n}^{-1} Z(z) h_{n^{\prime} n}(z)^{z} l_{n^{\prime} n}(z)^{1-z}
$$

$h_{n^{\prime} n}(z)$ and $l_{n^{\prime} n}(z)$ represent, respectively, the skills and labor allocated to its production; $Z(z)=$ $z^{-z}(1-z)^{z-1}$. Skill intensities are increasing in $z \cdot \tau_{n^{\prime} n}$ relates to the way firms obtain inputs: it takes value one if the firm produces the input in-house $\left(\tau_{n n}=1\right)$ and value $\tau_{n^{\prime} n}>1$ if it is sourced from outside the firm or from another location (offshored). This variable cost can be interpreted as a trade friction ${ }^{6}$ (in case goods are offshored) or as a cost or productivity disadvantage due to the outsourcing process. ${ }^{7}$ Outsourcing/offshoring of inputs is also subject to a fixed cost per

\footnotetext{
${ }^{5}$ We discuss additional restrictions on the value of $\varepsilon$ further below.

${ }^{6}$ We avoid modeling any type of contracting frictions that give rise to endogenous firm boundaries. See Antràs (2003) and Antràs and Helpman (2004). The model remains silent about whether imports of intermediates occur within or across firm boundaries.

${ }^{7}$ In principle, we can allow for $\tau_{n^{\prime} n}$ to vary by importing firm. Since we simply look at a firm's profit optimization problem, firm-varying trade frictions do not involve additional notation. With $\tau_{n^{\prime} n}$ varying across $\operatorname{country}-n$ firms,
} 
input $f^{o}$ in terms of the final good.

We assume no fixed costs of production and exporting, which implies all manufacturing firms operate in all markets. ${ }^{8}$ Factor and input markets are perfectly competitive. Each country's representative agent spends all the wage income and profits generated in her country.

\subsection{Offshoring decision}

The economic incentive for offshoring stems from reductions in the marginal cost of varieties achieved by exploiting international differences in factor prices: sourcing an input more cheaply reduces production costs and increases sales and profits.

\subsubsection{Cost functions}

Under the assumption that the manufacturing industry is very small relative to the numéraire good $(\beta \rightarrow 1)$, skill premia are inversely related to the skill abundance of countries, as in the evidence reported by Caselli and Coleman (2006): $w_{h 1} / w_{l 1}>w_{h 2} / w_{l 2}>\ldots>w_{h N} / w_{l N} \geq 1$ and $w_{l 1}<w_{l 2}<\ldots<w_{l N}$, where $w_{h n}$ and $w_{l n}$ denote the returns to country $n$ 's skills and labor, respectively. This result enables us to establish a link between skill premia and relative factor abundance, which is key in our empirical work. ${ }^{9}$

Given competitive factor markets and identical technologies to produce inputs, the presence of outsourcing frictions makes outsourcing goods within the firm's own country unprofitable. Country- $n$ firm's marginal cost of obtaining input $z$ from country $n^{\prime} \neq n$ is $p_{n^{\prime} n}(z) \equiv$ $\tau_{n^{\prime} n} w_{h n^{\prime}}^{z} w_{l n^{\prime}}^{1-z}$, whereas the marginal cost of producing an input in-house is $p_{n n}(z) \equiv w_{h n}^{z} w_{l n}^{1-z}$. Figure 1 plots the logarithms of these cost functions against $z$. We set $N=5$ and consider the offshoring decision from the perspective of a firm from country $n=3$. The lower envelope represents the lowest marginal costs $p_{n}(z)=\min \left\{p_{n^{\prime} n}(z) ; n^{\prime}=1, \ldots, N\right\}$ at which country- $n$ firms can obtain the different inputs. The cutoff points define the ranges of inputs for which each country has the corresponding lowest production costs: $p_{n^{\prime}-1 n}\left(z_{n^{\prime}-1}\right)=p_{n^{\prime} n}\left(z_{n^{\prime}-1}\right)$. (We define $z_{0}=0$ and $z_{N}=1$.) Input $z_{n^{\prime}-1}$ is equally expensive to offshore to countries $n^{\prime}-1$ and $n^{\prime}$, whereas inputs $z \in\left[z_{n^{\prime}-2}, z_{n^{\prime}-1}\right)$ are cheapest to offshore to country $n^{\prime}-1$. The range of inputs that are

the patterns we comment on below would just hold on average (provided $\tau_{n^{\prime} n}$ is uncorrelated with other countryand firm-features of the model).

${ }^{8}$ See Cuñat and Fadinger (2018) for an offshoring model with export fixed costs, which delivers complementarities between export and import decisions.

${ }^{9}$ It is easy to show that, when $\beta$ tends to $1, w_{h n}=[\alpha /(1-\alpha)]^{1-\alpha}\left(H_{n} / L_{n}\right)^{\alpha-1}$ and $w_{l n}=$ $[\alpha /(1-\alpha)]^{-\alpha}\left(H_{n} / L_{n}\right)^{\alpha}$. For $\beta<<1$, relative factor prices would also be affected by the relative-factor-demand effects induced by offshoring. In this case, since different countries may be subject to differences in transport costs $\tau_{n^{\prime} n}$, we would no longer be able to establish such a clear link between skill premia and factor-abundance ratios. 
cheapest to produce by country- $n$ firms domestically is defined by $p_{n-1 n}\left(z_{n-1}\right)=p_{n n}\left(z_{n-1}\right)$ and $p_{n+1 n}\left(z_{n}\right)=p_{n n}\left(z_{n}\right)$.

If the absence of fixed costs to offshoring $\left(f^{o}=0\right)$, all firms in country $n$ would import the range $\left[0, z_{n-1}\right)$ from labor-abundant countries, of which $\left[0, z_{1}\right)$ from country $1,\left[z_{1}, z_{2}\right)$ from country 2 , etc. Similarly, country- $n$ firms would offshore the range $\left[z_{n}, 1\right]$ to skill-abundant countries. ${ }^{10}$ For $f^{o}>0$, importing decisions will vary by firm within each country, as firms weigh the marginal benefit of offshoring an additional input (which depends on its productivity) against the marginal cost of offshoring $P f^{o}$.

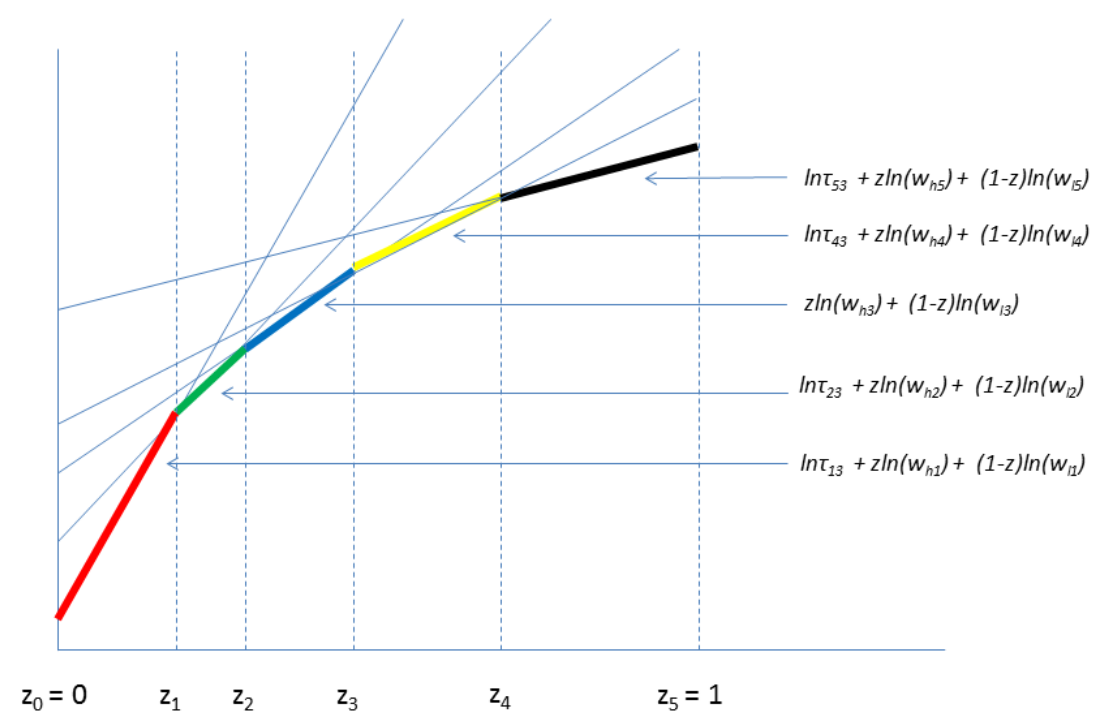

Figure 1: Minimum cost of sourcing vs. skill intensity

\subsubsection{Characterization of the offshoring decision}

Figure 1 shows that, within the set of labor-abundant countries relative to $n$, offshoring the most labor-intensive inputs to the most labor-abundant locations yields the largest cost savings to a country- $n$ firm. Similarly, offshoring the most skill-intensive inputs to the most skill-abundant locations yields the largest cost savings within the set of skill-abundant countries. Therefore,

\footnotetext{
${ }^{10}$ Suppose $\tau_{n^{\prime} n}$ is prohibitively large. Then the corresponding country- $n^{\prime}$ cost function would be so high up that no segment of it would be part of the lower envelope in Figure 1. In this case the country- $n$ firm would not offshore anything to country $n^{\prime}$.
} 
other things equal (including the cost of offshoring per input), more firms import from the extremes of the distributions of inputs and countries. Ceteris paribus, a country- $n$ firm would never offshore to a factor-abundant country without offshoring to an even more factor-abundant country, because sourcing from the latter would imply larger cost reductions and thereby larger increases in revenue. ${ }^{11}$

This implies that the offshoring decision of a country- $n$ firm with productivity $\gamma$ can be characterized by inputs $z_{n}^{-}(\gamma)$ and $z_{n}^{+}(\gamma)$, respectively the most skill-intensive input a country- $n$ firm with productivity $\gamma$ offshores to any labor-abundant country, and the most labor-intensive input offshored to any skill-abundant country. The range $\left(z_{n}^{-}(\gamma), z_{n}^{+}(\gamma)\right)$ is produced domestically by the country- $n$ firm. ${ }^{12}$ The actual cost function $M C_{n}\left(\gamma, z_{n}^{-}, z_{n}^{+}\right)$of any given country- $n$ firm depends on its offshoring pattern. Other things equal, firms that offshore a larger range of inputs will face lower production costs of their final varieties they produce. In Appendix A we show that the function $M C_{n}$ is continuous and differentiable, with $\partial M C_{n} / \partial z_{n}^{-}<0$ for any $z_{n}^{-}<z_{n-1}$ and $\partial M C_{n} / \partial\left(1-z_{n}^{+}\right)<0$ for any $z_{n}^{+}>z_{n} \cdot{ }^{13}$ As $z_{n}^{-}$increases, labor-intensive inputs produced in-house are substituted by imports from labor-abundant countries. This reduces the costs of a given country- $n$ final-good producer. $M C_{n}$ is convex in $z_{n}^{-}$for any $z_{n}^{-}<z_{n-1}$ (and in $\left(1-z_{n}^{+}\right.$) for any $z_{n}^{+}>z_{n}$ ): as $z_{n}^{-}$increases, the offshoring firm imports less and less labor-intensive inputs from labor-abundant countries. Thus, the resulting cost reductions become smaller as $z_{n}^{-}$grows. A symmetric result holds for offshoring to skill-abundant countries.

\subsubsection{Firm's optimal behavior}

Given factor prices and other firms' prices, firms maximize total profits $\Pi_{n}$, given by

$$
\max _{p_{n}, z_{n}^{-},\left(1-z_{n}^{+}\right)} p_{n}\left(\gamma, z_{n}^{-}, z_{n}^{+}\right) q_{n}\left(\gamma, z_{n}^{-}, z_{n}^{+}\right)-\left[M C_{n}\left(\gamma, z_{n}^{-}, z_{n}^{+}\right)\right] q_{n}-\left[z_{n}^{-}+\left(1-z_{n}^{+}\right)\right] P f^{o} .
$$

(We leave the corresponding mathematical details for Appendix A.) In the absence of fixed costs to offshoring $\left(f^{o}=0\right)$, all firms would offshore the same range of goods: $\left(z_{n}^{-}, z_{n}^{+}\right)=\left(z_{n-1}, z_{n}\right)$. The presence of offshoring fixed costs might make it optimal for a country- $n$ firm not to offshore some or any of the inputs for which other countries present lower costs (i.e., for $f^{o}>0,\left(z_{n-1}, z_{n}\right) \subseteq$ $\left.\left(z_{n}^{-}, z_{n}^{+}\right)\right)$, as the corresponding gains in variable profits may not compensate the involved costs

\footnotetext{
${ }^{11}$ We offer a formal proof of this argument in Appendix A.

${ }^{12}$ Country-1 firms cannot offshore to a more labor-abundant country: $z_{1}^{-}=0$ for all country-1 firms. Similarly, country- $N$ firms cannot offshore to a more skill-abundant country: $z_{N}^{+}=1$.

${ }^{13}$ Framing the offshoring decision towards skill-abundant countries in terms of $\left(1-z_{n}^{+}\right)$rather than $z_{n}^{+}$renders the analysis more symmetric.
} 
to offshoring.

Since high-productivity firms have larger market shares, the reduction in marginal costs resulting from offshoring is translated into larger variable profits than in the case of low-productivity firms. We should therefore expect more productive firms to offshore inputs that less productive firms choose to produce in-house. The latter concentrate on offshoring the inputs that, other things equal, produce the largest cost savings, as these are their only offshoring choices for which the resulting gains in profits compensate the involved fixed costs. This intuition therefore suggests that firms with higher productivity will offshore not only the most labor-intensive inputs, produced by the most labor-abundant countries, but also some of the not so labor-intensive inputs, produced by not so labor-abundant countries. (The symmetric intuition applies for imports of skill-intensive inputs from skill-abundant countries.) In Appendix A we prove that $\partial z_{n}^{-}(\gamma) / \partial \gamma \geq 0$ and $\partial\left(1-z_{n}^{+}(\gamma)\right) / \partial \gamma \geq 0$ under the sufficient condition $\sigma \geq \varepsilon>1$. The less substitutable inputs are (that is, the smaller $\varepsilon$ is), the larger the reduction of production costs from offshoring an additional one. The higher the elasticity of substitution between final varieties $\sigma$, the larger the amount by which the cost reduction is turned into additional profits. When $\sigma>\varepsilon$, a given cost reduction translates into a more than a one-to-one profit increase, and this effect is amplified by a larger $\gamma$ with an elasticity of $\varepsilon-1 .^{14}$

In general, it is impossible to tell whether firms will first offshore to labor-abundant or skillabundant locations. This depends on the offshoring costs and the size of factor-price differences across countries. Note that $\tau_{n^{\prime} n}$ reflects not only transport costs (widely understood), but also the productivity levels of foreign suppliers. In the case of France, a skill-abundant country close to other similarly endowed locations, it turns out that firms mainly source from neighboring skill-abundant locations (with low $\tau_{n^{\prime} n}$ ). ${ }^{15}$ Only highly productive firms also source from laborabundant locations, which feature high offshoring $\operatorname{costs} \tau_{n^{\prime} n}$.

\subsection{Sourcing patterns}

In a nutshell, the model predicts that more productive firms import inputs with a wider range of skill intensities; this in turn implies that more productive firms import from countries with a

\footnotetext{
${ }^{14}$ Our discussion might give the false impression that there are no complementarities between inputs in the firm's offshoring decision. On the contrary, the model features complementarities in sourcing decisions across inputs similar to those in Antràs et al. (2017): importing a given input $z$ reduces the firm's marginal cost and thereby increases its sales and profits, which may make it worthwhile to import additional inputs. However, in our setup the cost gains from offshoring different inputs can be clearly ranked according to factor-price differences. This simplifies the sourcing decision considerably.

${ }^{15}$ See Section 4.
} 
wider range of relative factor abundance. ${ }^{16}$ We now elaborate on this result in order to justify the econometric specifications we use below, which connect firm-level productivity with the specific types of inputs offshored and their sourcing locations. ${ }^{17}$ Consider a firm with productivity $\gamma$ located in country $n$ sourcing input $z$ from country $n^{\prime}$. The logarithm of the import value of a given input $z$ is

$$
\begin{aligned}
& \log \left[p_{n^{\prime} n}(z) x_{n^{\prime} n}(z)\right]=\Delta+(1-\varepsilon) \log \left(\tau_{n^{\prime}, n}\right)+(1-\varepsilon) \log \left(w_{l n^{\prime}}\right)+ \\
& +(1-\varepsilon) z \log \left(w_{h n^{\prime}} / w_{l n^{\prime}}\right)+(\sigma-1) \log (\gamma)+(\varepsilon-\sigma) \log M C_{n}\left(\gamma, z_{n}^{-}, z_{n}^{+}\right)
\end{aligned}
$$

where $\Delta \equiv-\sigma \log \left(\frac{\sigma}{\sigma-1}\right)+\log (D) . D$ collects the terms that affect demand (world expenditure on goods produced by the industry, the corresponding consumer price index) but are given from the individual firm's perspective. The import value increases in productivity $\gamma,{ }^{18}$ and decreases in offshoring $\operatorname{cost} \tau_{n^{\prime} n}$, the unskilled wage $w_{l n^{\prime}}$, which is larger for more skill-abundant countries, and in the interaction of skill intensity $z$ and the skill premium $w_{h n^{\prime}} / w_{l n^{\prime}}$. This term implies that more skill-abundant countries have a lower cost for and hence a comparative advantage in producing more skill-intensive inputs (intensive margin).

For firms offshoring to labor-abundant countries, the skill intensity of the marginal input offshored to country $n^{\prime}, z_{n}^{-}(\gamma)$, increases in $\gamma$. When considering importers from a specific laborabundant country $n^{\prime}$, the value of imports of relatively skill-intensive products will be larger for more productive firms, since import values in equation (5) are positive for $z \in\left[z_{n^{\prime}-1}, \min \left\{z_{n^{\prime}}, z_{n}^{-}(\gamma)\right\}\right]$, while the opposite will be true for firms offshoring to skill-abundant locations: ${ }^{19}$

\footnotetext{
${ }^{16}$ We thank an anonymous referee for this formulation.

${ }^{17}$ In general, our results apply to firms in any country except for those in the most skill-abundant and laborabundant countries, that is countries 1 and $N$, where the offshoring patterns are rather "one-sided" for obvious reasons.

${ }^{18}$ For $\sigma>\varepsilon$ higher productivity also has an indirect positive impact on import values through its effect on the offshoring cutoffs $z_{n}^{-}(\gamma)$ and $z_{n}^{+}(\gamma)$, captured by the term $(\varepsilon-\sigma) \log M C_{n}\left[\gamma, z_{n}^{-}(\gamma), z_{n}^{+}(\gamma)\right]$. This reflects complementarities in sourcing decisions: higher productivity implies that more inputs are offshored, which reduces marginal costs and thus increases the value of imports for a given input.

${ }^{19}$ In our stylized model, the only country for which the marginal offshored input is a function of $\gamma$ is actually country $n^{-}$. In the presence of input-country-firm-specific stochastic fixed offshoring costs, however, the skillintensity of the marginal good sourced from each country would be a function of the importing firm's $\gamma$. In order for offshoring input $z_{n}^{\prime}$ to country $n^{\prime}$ to be profitable,

$$
\frac{\partial \Pi_{n}}{\partial z_{n}^{\prime}}=-M C_{n}^{1-\sigma}(\gamma)\left(\frac{\sigma}{\sigma-1}\right)^{-\sigma} B_{n^{\prime} n} D \geq f^{o} .
$$

Letting $f^{o}$ be stochastic and input-country-firm-specific, drawn from a distribution $G\left(f^{o}\right)$ which is i.i.d across firms, countries and inputs, the probability of good $z_{n}^{\prime}$ being offshored to country $n^{\prime}$ would be $G\left[-\left(\frac{\sigma}{\sigma-1}\right)^{-\sigma} M C_{n}^{1-\sigma}(\gamma) B_{n^{\prime} n} D\right]$, which is increasing in $\gamma$ and decreasing in skill intensity $z$ (see the Appendix for the definition of $B_{n^{\prime} n}$ ). Therefore, in expectations cost gains from offshoring to labor-abundant countries are still largest for the most labor-intensive inputs, which - on average - are sourced from the most labor-abundant
} 
Prediction 1 (Sourcing, input skill intensity and productivity): For labor-abundant source countries, the import value of relatively skill-intensive inputs is larger for more productive firms. (The symmetric statement holds for skill-abundant source countries. ${ }^{20}$

Next, we look at firms' decisions from which countries to source. Consider two firms with productivity levels $\gamma_{1}<\gamma_{2}$ sourcing from country $n^{\prime}, n^{\prime}<n^{\prime}+1<n$. If firm 2 is sufficiently more productive than firm 1, it will also source from more skill-abundant countries (represented by $n^{\prime}+1$ in this example), whereas the less productive firm 1 will not. Hence import values are positive for $z \in\left[0, \min \left\{z_{n^{\prime}}, z_{n}^{-}(\gamma)\right\}\right], z_{n}^{-}\left(\gamma_{1}\right)<z_{n}^{-}\left(\gamma_{2}\right)$. (The symmetric result applies as well for importers from skill-abundant countries.)

Prediction 2 (Sourcing, country skill abundance and productivity): For firms offshoring to the set of labor-abundant countries, more productive firms import larger values from relatively more skill-abundant locations within that set. (The symmetric statement holds for skill-abundant source countries. $)^{21}$

\subsection{Firm-level predictions on domestic skill intensity}

We now turn to the link between offshoring and domestic relative factor demands. The model predicts that self-selection into offshoring leads to within-industry variation in the skill intensity of domestic production, since firms choose to offshore different ranges of inputs which vary in their skill intensities. To see this, define the skill intensity of domestic production of a firm located in country $n$ as

$$
\frac{\int_{z_{n}^{-}(\gamma)}^{z^{+}(\gamma)} h_{n n}(z) d z}{\int_{z_{n}^{-}(\gamma)}^{z_{n}^{+}(\gamma)} l_{n n}(z) d z}=\frac{w_{l n}}{w_{h n}} \frac{\int_{z_{n}^{-}(\gamma)}^{z_{n}^{+}(\gamma)} z p_{n n}^{1-\varepsilon}(z) d z}{\int_{z_{n}^{-}(\gamma)}^{z_{n}^{+}(\gamma)}(1-z) p_{n n}^{1-\varepsilon}(z) d z}=\frac{w_{l n}}{w_{h n}} \Delta
$$

It is easy to see that $\partial \Delta / \partial z_{n}^{-}>0$ and $\partial \Delta / \partial\left(1-z_{n}^{+}\right)<0$. Thus, the domestic skill intensity of offshoring firms increases if they source from labor-abundant countries and decreases in case they source from skill-abundant countries. ${ }^{22}$

countries. Moreover, in this case the marginal input sourced from a given location would vary across firms even for infra-marginal countries. Finally, since the marginal gain from offshoring more skill intensive inputs is strictly increasing in $\gamma$ as long as $\sigma>\varepsilon$, the skill intensity of the marginal input offshored to each labor-abundant country would be on average larger for more productive firms.

${ }^{20}$ The model also yields the related prediction that more productive offshoring firms have more variation in the skill intensity of their imported goods from a given country.

${ }^{21}$ One can also show that more productive offshoring firms have more variation in the skill abundance of countries from which they import.

${ }^{22}$ Firms producing all inputs in-house will have the same skill intensity. These are the firms with productivity $\gamma<\gamma_{n}^{o}$ and $z_{n}^{-}(\gamma)=0$ and $z_{n}^{+}(\gamma)=1$. Hence, the variation in skill intensity of domestic production is larger across 
Prediction 3 (Offshoring status and domestic skill intensity): Offshoring to laborabundant countries raises the skill intensity of firms in their domestic production. (The symmetric statement holds for skill-abundant countries.)

Define firm-level import intensity as the import share in total variable cost. A country- $n$ firm's import intensity from labor-abundant countries is given by

$$
\frac{\left[\sum_{n^{\prime}=1}^{n^{-}-1} \int_{z_{n^{\prime}-1}}^{z_{n^{\prime}}} p_{n^{\prime} n}^{1-\varepsilon}(z) d z+\int_{z_{n^{-}-1}}^{z_{n}^{-}(\gamma)} p_{n^{-} n}^{1-\varepsilon}(z) d z\right]}{\gamma^{1-\varepsilon} M C_{n}^{1-\varepsilon}}
$$

which increases in $z_{n}^{-}(\gamma)$. Similarly, the import intensity from skill-abundant countries increases in $1-z_{n}^{+}(\gamma)$. Above we showed that the skill intensity of domestic production increases in $z_{n}^{-}(\gamma)$ and decreases in $1-z_{n}^{+}(\gamma)$. We thus have the following result:

Prediction 4 (Offshoring intensity and domestic skill intensity): The skill intensity of domestic production increases in the import intensity from labor-abundant countries. (The symmetric statement holds for skill-abundant countries. $)^{23}$

\subsection{Reductions in offshoring costs to labor-abundant countries}

We now investigate the impact of reductions in offshoring costs to labor-abundant countries on offshoring decisions and domestic skill intensities. Note that reductions in $\tau_{n^{\prime} n}, n^{\prime} \leq n^{-}$, raise the import intensity from labor-abundant countries (7) through both the intensive margin (a larger import intensity of infra-marginal offshored inputs) and the extensive margin (an increase in $\left.z_{n}^{-}\right){ }^{24}$

The effect of reducing $\tau_{n^{\prime} n}$ on the extensive margin $z_{n}^{-}(\gamma)$ operates through two distinct mechanisms. First, consider a uniform reduction in $\tau_{n^{\prime} n}$ equal to $-\Delta \tau$ for all inputs sourced from labor-abundant countries. For firms with $z_{n}^{-}(\gamma)>0$, such a reduction in $\tau$ makes all inframarginal offshored inputs cheaper. This reduces the offshoring firm's marginal cost $M C_{n}(\gamma)$, which raises its production scale and profits and thus makes an increase in $z_{n}^{-}(\gamma)$ optimal. Notice that this argument has less bite for low-productivity firms with $z_{n}^{-}(\gamma)$ close to zero, as the range of inframarginal offshored inputs is very small. In this regard, in the Appendix we prove that a uniform decrease in variable offshoring costs across all labor-abundant sourcing countries raises

offshoring firms than across firms that source all inputs domestically.

${ }^{23}$ One can also show that the skill intensity of domestic production increases in the skill intensity of imports from labor-abundant and skill-abundant countries.

${ }^{24}$ In the Appendix we show that $z_{n}^{-}$depends negatively on $\tau_{n^{\prime} n}, n^{\prime} \leq n^{-}$. 
the $z_{n}^{-}(\gamma)$ of a high-productivity firm (with $z_{n}^{-}\left(\gamma_{2}\right)>0$ ) relative to that of a low-productivity firm (with $z_{n}^{-}\left(\gamma_{1}\right)$ close to zero). Since (6) only depends on offshoring via the extensive margin $z_{n}^{-}(\gamma)$ and $z_{n}^{+}(\gamma)$, a given reduction in offshoring costs to labor-abundant countries then implies a larger increase in domestic skill intensity for high-productivity compared to low-productivity offshorers. A reduction in offshoring cost to labor-abundant countries also reduces $z_{n}^{+}(\gamma)$, thereby increasing import intensity from skill-abundant locations and reducing domestic skill intensity. In the empirical specifications, we will control for this indirect effect of reductions in offshoring costs to labor-abundant countries.

Second, a reduction in the offshoring cost to the firm's "marginal country" (that is, the country from which the firm offshores input $\left.z_{n}^{-}(\gamma)\right)$ also raises the offshoring cutoff: since this input can now be sourced at a lower cost, the firm will have an incentive to replace additional inputs produced in-house with imports. Thus, if offshoring costs to labor-abundant locations fell more for the most skill-intensive inputs (or the most skill-abundant countries among them), this would favor high-productivity firms in country $n$ disproportionately relative to low-productivity firms. For the latter, these inputs are neither marginal nor inframarginal. This implies that low-productivity firms would not reap any gains from such a reduction in offshoring costs. Thus, the domestic skill intensities of high-productivity firms would rise even more relative to those of low-productivity firms. 


\section{Data}

\subsection{Firm-level data}

Our empirical analysis is based on a detailed French firm-level dataset that we obtain by merging several administrative data sources using a common firm identifier.

Trade: Firm-level trade data come from an exhaustive administrative file collected by the French Customs Office. The yearly value of imports (by country of origin and product) and exports are reported for all firms over the period 1996-2007. ${ }^{25}$ As explained in the model section, we interpret offshoring broadly, as an activity that splits a production process across countries regardless of whether inputs are sourced within or across firm boundaries. This also includes extreme cases where the full physical production process is offshored and only typical headquarter inputs (marketing, accounting, $\mathrm{R} \& \mathrm{D}$ ) are produced domestically. Thus, we do not restrict imports to be intermediates and do not condition trade to occur between affiliated parties, but consider instead all firms' imports of manufacturing products (including those of final goods). The data do not allow us to observe domestic outsourcing decisions. Our model implies that domestic outsourcing is never profitable. We also use yearly sectoral export, import and production data at the 4-digit NAF Rev2 level ${ }^{26}$ for France from French official statistics to construct a measure of sector-specific import competition in France, defined as import com-

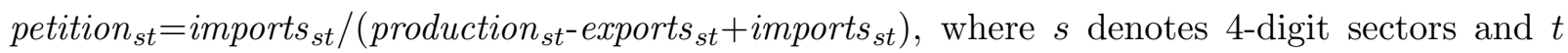
denotes years.

Balance sheet: The administrative BRN dataset ("Bénéfices Réels Normaux") is constructed from tax records and provides firm-level balance-sheet information by year. We use data on sales, value added, employment, material usage, capital stock and main sector of activity at the 5-digit NAF Rev2 level. We deflate value added and capital stocks using industry-level price indices provided by the French statistical agency. The dataset includes over $60 \%$ of French firms.

We use the BRN dataset together with information from DADS (see below) to estimate firm-level value-added-based total factor productivity (TFP) as the residual of a 3-factor CobbDouglas production function with skilled labor, unskilled labor and capital inputs. ${ }^{27}$ We estimate

\footnotetext{
${ }^{25}$ The data is virtually exhaustive. Flows with non-EU countries whose value is below 1,000 Euros are not in the dataset. In the case of EU countries, the threshold is larger, varying from 40,000 to 150,000 Euros depending on the year. These thresholds leave out a very small proportion of French trade flows.

${ }^{26} \mathrm{NAF}$ is the French classification of economic activities, the first four digits of which are identical to the NACE Rev2 classification.

${ }^{27}$ Recent structural work on the impact of offshoring on firm-level productivity includes Halpern, Koren and Szeidl (2015) and Blaum, Lelarge and Peters (2018). These papers posit Cobb-Douglas production functions, which imply constant input shares. As made clear by our theoretical model, such an approach is not adequate
} 
production functions separately for each 2-digit industry using data on 646,920 observations over the period 1996-2007. Our preferred measure uses the Levinsohn and Petrin (2003) method, but we obtain very similar results with Wooldrige's (2009) approach. The coefficient estimates of the sector-specific production functions are reported in Table A-2.

Employment by skill: We obtain information on the occupational structure at the firm level using the DADS dataset ("Déclaration Annuelle de Données Sociales"). DADS is constructed from mandatory employer reports of their workers' characteristics. For every firm in France with at least one employee, we have information on the number of workers by year in each of five categories: $2=$ Firm owners receiving a wage; $3=$ Administrative and commercial managers (includes engineers); $4=$ Technicians and supervisors; $5=$ White-collar employees; $6=$ Production workers (Blue Collar). Categories are based on the French Nomenclature des professions et catégories socioprofessionnelles, PCS. ${ }^{28}$ We construct our main measure of skill intensity at the firm level as the fraction of non-production workers relative to blue-collar employment. The skill intensity of firm $f$ in year $t$ is defined as skill intensity $f t \equiv(2+3+4+5) /(6)$. In Table A-3 we show that non-production workers are significantly more skilled than production workers as proxied by their relative wages (skill premium).

\subsection{Country- and product-level data}

We complement our firm-level dataset with the following information:

Country-level human-capital: In the model skill premia are inversely related to relative factor endowments. We use information on country-level skill abundance from Barro and Lee (2013) to construct the set of countries which are more labor abundant than France. Our measure of skill abundance is the number of years of secondary schooling per capita in the population older than 15. We consider the set of countries that have less than 95 percent of the French level of secondary education as labor abundant and the remaining set of countries as skill abundant. Our empirical results are not sensitive to this specific choice. ${ }^{29}$ The information on secondary education is

in our context, as all factor shares are firm-specific and endogenous to sourcing decisions. We leave developing a methodology for theory-consistent estimation of TFP in this setup to future work and instead use a standard method to compute TFP. In order to avoid mis-measurement problems, we never use TFP as an outcome variable. Instead, we use initial-period TFP as a crude proxy for the true productivity level.

${ }^{28}$ The nomenclature underwent a change in 2003. This change only affected the 3 -digit disaggregation, while the 1-digit classification we are using remained unchanged. Although this variable refers to occupations, it has often been used to proxy for the workers' skill level (e.g., Cahuc et al., 2006). Caliendo et al. (2015) show that average wages are inversely linked to the position in the PCS.

${ }^{29}$ In unreported robustness checks we have also used an 80-percent threshold for labor-abundant countries and a 105-percent threshold for skill-abundant countries. We have alternatively dropped Hong Kong, Japan, Singapure and Taiwan from the set of labor-abundant countries, since they are arguably skill-abundant and we have dropped 
available for the years 2000 and 2005; we use an average of the two data points. Table A-4 presents the set of countries and the schooling endowments relative to those of France. ${ }^{30}$

Product-level skill-intensity data: We use the NBER manufacturing database (Bartelsman and Gray, 1996; available at http://www.nber.org/nberces/) to construct measures of skill intensity at the product level. The data are available up to 2005. We define skill intensity as the ratio of non-production workers to total employment. Both measures are available at the NAICS97 6-digit level. We map them into HS6 codes using the concordance table provided by Pierce and Schott (2009). When more than one NAICS97 code maps into a single HS6 code, we take a simple average. The advantage of using U.S. industry data is that it is exogenous to events in France. To further avoid endogeneity issues, we use factor intensity in the pre-sample year 1995 .

World Exports: We use data from the BACI database (administered by CEPII) to construct exports by HS 6-digit product for each country from which French firms import for the years 1996 to 2007. We use this information to construct instrumental variables based on supply shocks in France's trading partners.

\section{Construction of instrumental variables}

In order to exploit exogenous variation in offshoring opportunities, we construct instruments for the value of imports by firm from the sets of labor- and skill-abundant countries. According to our model, changes in $\tau_{n^{\prime} n}$ shift both $p_{n^{\prime} n}(z) x_{n^{\prime} n}(z)$ and the offshoring thresholds $z_{n}^{-}(\gamma)$ and $z_{n}^{+}(\gamma)$, and thereby impact on import intensity. Changes in $\tau_{n^{\prime} n}$ capture, among other things, variation in the productivity of foreign export-suppliers. We construct an instrument for the endogenous variables which exploit variation in world export-supply shocks, following recent work by Autor et al. (2013).

This instrument is based on the following idea: an increase in world exports of product $p$ by country $n$ to the rest of the world reflects a shock in country $n$ 's competitiveness for this product (due, for example, to exogenous variation in productivity, costs or product quality). French firms importing product $p$ from this location would respond to the shock by increasing their imports of this product from this specific origin. Exogeneity is ensured by the fact that foreign export-supply shocks to the rest of the world are exogenous to firm-level decisions in France. To construct such

a number of Eastern European and central Asian countries from the set of skill-abundant countries, which are arguably not really skill-abundant. In all cases, our results remained unchanged. These results are available upon request.

${ }^{30}$ We consider as skill-abundant any old EU-member countries that fall below these cutoffs (Belgium, Denmark, Finland, Greece, Ireland, Italy, Luxemburg, Portugal, Spain and the UK), since they are all marginal cases. However, most of our empirical results are robust to including them in the set of labor-abundant countries. 
firm-specific instruments, we rely on Hummels et al. (2014). For each firm, we compute the share of each (HS6) product-country pair in total imports in the first year the firm appears in the sample in order to avoid endogeneity concerns and then take an import-share-weighted average of foreign export supply shocks. Specifically, let $X_{p, n, t}$ be the total export supply of product $p$ by country $n$ in period $t$ (excluding exports to France), and let $w_{f, p, n, 0}$ be the share of imports of product $p$ from country $n$ in firm $f$ 's imports from labor-abundant countries in the first period the firm is in the sample. Then the firm-specific instrument for the value of imports from labor-abundant countries is constructed as

$$
\widehat{\text { imports }} s_{f, t}=\sum_{n \in I_{f, n, 0}} \sum_{p \in I_{f, p, 0}} w_{f, p, n, 0} \times \log (X)_{p, n, t}
$$

where $I_{f, n, 0}$ and $I_{f, p, 0}$ is the set of countries and products a given firm imports in the first year it is in the sample. Our identification strategy will exploit exogenous within-firm time variation in the instrument due to export-supply shocks at the country-product level. Given that we use the $\log$ of $X_{p, n, t}$, this corresponds to using growth rates of export supply weighted with firmspecific import shares. Moreover, given that we use initial imports as weights, the instrument operates only through the intensive margin of imports. We construct an instrument for the value of imports from skill-abundant countries in an analogous way. In order for the supply-shockbased instruments to have sufficient power, two conditions must be satisfied: the set of imported products must have sufficient variation across firms; and it must relatively stable over time for a given firm. Both conditions are met in our data. ${ }^{31}$

\section{Estimating sample}

We restrict the sample to firms in manufacturing and we only consider imports of manufactured goods. ${ }^{32}$ The resulting estimating sample is an unbalanced panel covering 1996 to 2007 with 646,920 firm/year observations corresponding to 104,036 firms. Of these, 37,847 firms import at least once from skill-abundant countries and 25,296 import at least once from labor-abundant countries. ${ }^{33}$ The average number of HS 6-digit products per firm sourced from skill-abundant

\footnotetext{
${ }^{31}$ Carluccio et al. (2015) provide detailed evidence in favor of these points for the firms in our sample.

${ }^{32}$ We keep firms in the two-digit NACE Rev2 industries 10-33, with the exception of natural resource-based codes 12 (Manufacture of tobacco products) and 19 (Manufacture of coke and refined petroleum products). We exclude imports of raw materials (HS01-15, 23, 25-27, 31 and 41) and services (HS97-99). Excluded import flows account for around $5 \%$ of total imports over the period.

${ }^{33}$ To mitigate measurement error, we consider firms as importers when they import for at least two consecutive years.
} 
(labor-abundant) countries is $10(6)$, and the average number of countries per product is 1.74 . Consistently with the model, the vast majority of firms sources a given product from only one country. Table A-1 in the Appendix presents summary statistics of firm-level variables.

\section{Descriptive Evidence}

In this section we describe some of the salient features of the French administrative firm-level data described above.

\subsection{Intra-industry heterogeneity in skill intensity}

Intra-industry heterogeneity in skill intensity is pervasive in the data. Moreover, as in our model, it is larger for offshoring firms compared to firms that do not import. The left panel of Figure 2 plots the kernel density of the firm-level $(\log )$ skill intensity. The variable of interest has been demeaned at the 4-digit sector level, so that the density can be interpreted as pure within-industry heterogeneity in firm-level $(\log )$ skill intensity. The distribution is approximately normal, with a rather sizable standard deviation of 1.628. We also decompose the variance of (log) skill intensity in French manufacturing into between and within 4-digit-sector variation: 80 percent of the variance of $(\log )$ skill intensity is explained by within-sector variation between firms, while only 20 percent of the variation is between sectors (result not reported). The right panel of Figure 2 plots kernel densities of (log) skill intensity separately for importers and non-importing firms. The distribution of firms that import displays a much larger dispersion than the distribution of non-importers.

\subsection{Imports and domestic skill intensity}

During the sample period, offshoring to labor-abundant countries gained much relevance in French manufacturing. The left panel of Figure 3 presents the aggregate trend in offshoring to laborabundant countries, measured as the fraction of firms' imports originating in labor-abundant countries (measured on the left axis): from 1996 to 2007 there was a large increase in the share of these imports, from less than 16 to more than 20 percent of total French manufacturing imports. The left panel also suggests that the trends in skill intensities and offshoring patterns might be related. It presents the aggregate trend in skill intensity in French manufacturing (right axis): the aggregate skill intensity of manufacturing production increased by around 10 log points (around 10.5 percentage points), tracking imports from labor-abundant countries quite closely. 

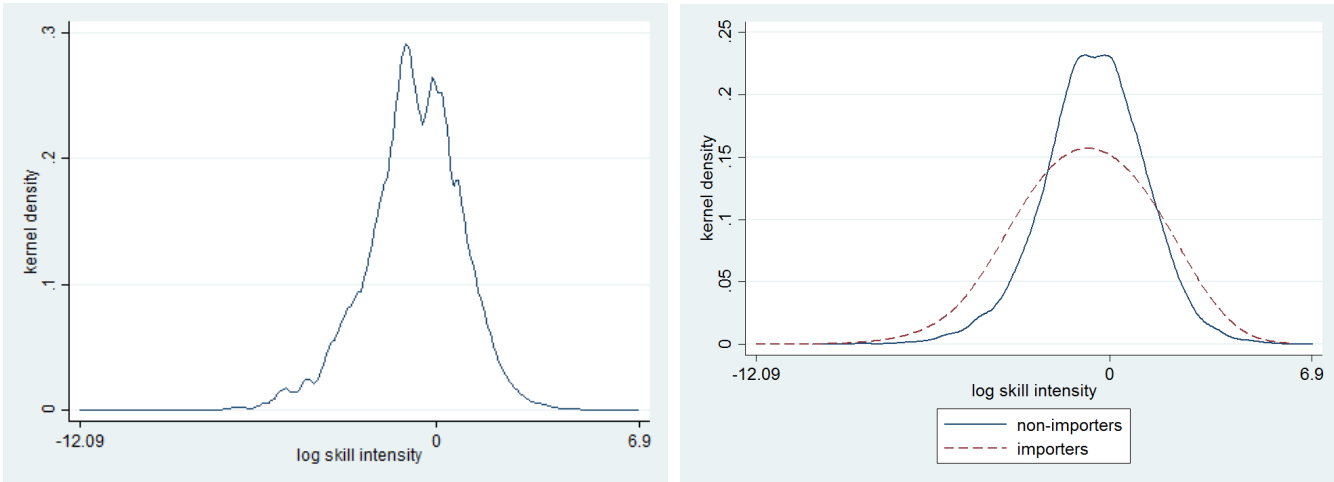

Figure 2: Distribution of log skill intensity.

The left panel plots the distribution of the firm-level log skill intensity, defined as the log ratio of employment of non-blue collar workers to blue-collar production workers per firm. The right panel plots the distributions separately for importers and non-importers. Observations are deviations from the 4-digit industry means. Thus, the distributions show the within-sector dispersion in firm-level log skill intensity.
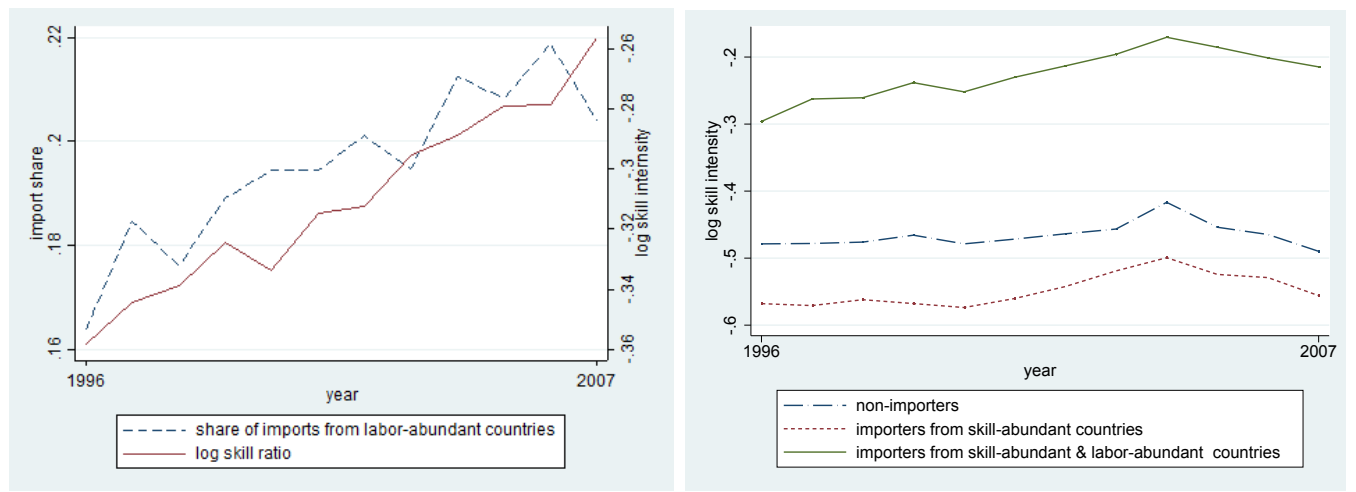

Figure 3: Trend in imports from labor-abundant countries and trends in skill intensity.

The left panel plots the share of imports originating in labor-abundant countries (countries with less than 95 percent of the French level of secondary schooling) in total French manufacturing imports (left axis) and the aggregate skill intensity, defined as the ratio of non-blue collar to blue-collar employment in French manufacturing (right axis). The right panel plots the average firm-level log skill intensity, separately for three categories of firms: firms that exclusively import from skill-abundant countries (with more than 95 percent of the French level of secondary schooling); firms that import from labor-abundant (with less than 95 percent of the French level of secondary schooling) and from skill-abundant of countries; firms that do not import.

The right panel of Figure 3 plots the mean (log) skill intensity of French manufacturing firms by import status over time: firms importing from both skill- and labor-abundant countries are more skill intensive in their domestic production than non-importers and have experienced a large increase in their domestic skill intensities over time. By contrast, firms exclusively importing from skill-abundant countries are more labor intensive than non-importers. Moreover, the skill intensity of the last two groups has not changed significantly during the sample period. This 
suggests that: 1) domestic skill intensity is related to the skill abundance of the offshoring destinations; 2) increases in domestic skill intensity are related to importing from labor-abundant countries.

Table 1 reports the average skill intensity and total factor productivity (TFP) by year separately for the same three categories of firms. The number of non-importers declined significantly during the sample period (from 30,806 to 23,658). Since the number of active firms simultaneously went down by 17 percent (from 48,282 to 40,072), the share of non-importers declined only slightly (from 63 to 59 percent). Similarly, the number of exclusive importers from skill-abundant countries heavily contracted (from 11,889 to 7,503). Differently, the number of firms importing from both sets of countries (from 5,317 to 7,818 ) increased substantially. Thus, there has been a substantial shift towards importing from labor-abundant countries at the extensive margin, too. Table 1 also confirms the patterns on skill intensity by import status visible in Figure 2. It also shows that importers from all categories of countries display a larger dispersion in skill intensities than non-importers, as measured by the standard deviation of skill intensity.

\subsection{Imports and productivity}

Table 1 also reports average TFP levels by import status. We normalize average TFP to zero for each 4-digit-sector-year pair, so that numbers are to be interpreted as TFP relative to the sector-year average. It turns out that firms' import status can be ranked in terms of productivity: in comparison with the average firm in the sector, the average non-importer is 3.5 percent less productive; the average importer from skill-abundant countries is 4.5 percent more productive; and firms that import from both sets of countries are on average 11.5 percent more productive. ${ }^{34}$

The productivity premium of firms importing from both sets of countries has fallen over time, from around 14 percent to around 9.5 percent, while the relative productivity of all other categories has stayed roughly constant. This suggests a change in the way importers are selected on TFP: less productive firms start to also import from labor-abundant countries. Together with the fact that the number of importers from both sets of countries has increased a lot over time, while the number of exclusive importers from skill-abundant countries has fallen, this suggests that offshoring costs to labor-abundant countries have declined disproportionately.

\footnotetext{
${ }^{34}$ There is also a smalll number of exclusive importers from labor-abundant countries: between 600 and 1200 firms fall into this category. On average, they are around one percent more productive than non-importers and they also experienced a substantial increase in their domestic skill intensity during the sample period. Since this category is marginal and not consistent with the baseline version of our model without stochastic fixed costs which implies that all importers from labor-abundant countries should also source from skill-abundant countries we omit it here for simplicity.
} 


\begin{tabular}{|c|c|c|c|c|c|c|c|c|c|c|c|c|}
\hline \multicolumn{5}{|c|}{ Non-Importers } & \multicolumn{4}{|c|}{$\begin{array}{l}\text { Importers skill-abundant } \\
\text { countries }\end{array}$} & \multicolumn{4}{|c|}{$\begin{array}{l}\text { Importers labor-abundant } \\
\text { \& skill-abundant countries }\end{array}$} \\
\hline Year & Obs. & $\begin{array}{c}\text { Mean } \\
\text { skill int. }\end{array}$ & $\begin{array}{c}\text { St.d. } \\
\text { skill int. }\end{array}$ & $\begin{array}{l}\text { Mean } \\
\text { TFP }\end{array}$ & Obs. & $\begin{array}{c}\text { Mean } \\
\text { skill int. }\end{array}$ & $\begin{array}{c}\text { St.d. } \\
\text { skill int. }\end{array}$ & $\begin{array}{l}\text { Mean } \\
\text { TFP }\end{array}$ & Obs. & $\begin{array}{c}\text { Mean } \\
\text { skill int. }\end{array}$ & $\begin{array}{c}\text { St.d. } \\
\text { skill int. }\end{array}$ & $\begin{array}{l}\text { Mean } \\
\text { TFP }\end{array}$ \\
\hline 1996 & 30,386 & -0.479 & 0.932 & -0.036 & 11,889 & -0.568 & 0.992 & 0.056 & 5,317 & -0.296 & 1.046 & 0.133 \\
\hline 1997 & 30,815 & -0.478 & 0.933 & -0.038 & 12,471 & -0.571 & 0.974 & 0.055 & 5,783 & -0.263 & 1.080 & 0.142 \\
\hline 1998 & 29,296 & -0.476 & 0.939 & -0.036 & 12,552 & -0.562 & 0.980 & 0.046 & 6,093 & -0.261 & 1.084 & 0.129 \\
\hline 1999 & 29,670 & -0.466 & 0.94 & -0.038 & 12,353 & -0.568 & 0.972 & 0.050 & 6,402 & -0.238 & 1.080 & 0.129 \\
\hline 2000 & 28,298 & -0.479 & 0.946 & -0.035 & 11,980 & -0.574 & 0.987 & 0.037 & 6,766 & -0.252 & 1.077 & 0.122 \\
\hline 2001 & 27,810 & -0.472 & 0.944 & -0.032 & 10,502 & -0.560 & 0.968 & 0.040 & 6,769 & -0.230 & 1.109 & 0.110 \\
\hline 2002 & 29,110 & -0.464 & 0.941 & -0.031 & 10,429 & -0.542 & 0.971 & 0.039 & 7,115 & -0.213 & 1.093 & 0.109 \\
\hline 2003 & 28,040 & -0.456 & 0.943 & -0.033 & 10,051 & -0.519 & 0.979 & 0.040 & 7,163 & -0.196 & 1.091 & 0.111 \\
\hline 2004 & 27,328 & -0.418 & 0.965 & -0.035 & 9,799 & -0.499 & 0.987 & 0.039 & 7,495 & -0.170 & 1.077 & 0.112 \\
\hline 2005 & 26,866 & -0.454 & 0.949 & -0.035 & 9,407 & -0.524 & 0.973 & 0.038 & 7,878 & -0.185 & 1.074 & 0.107 \\
\hline 2006 & 26,971 & -0.465 & 0.955 & -0.036 & 8,717 & -0.529 & 0.988 & 0.045 & 8,059 & -0.201 & 1.062 & 0.104 \\
\hline 2007 & 23,658 & -0.490 & 0.957 & -0.036 & 7,503 & -0.556 & 0.980 & 0.045 & 7,818 & -0.215 & 1.060 & 0.096 \\
\hline All & 338,248 & -0.466 & 0.945 & -0.035 & 127,653 & -0.550 & 0.980 & 0.045 & 82,658 & -0.223 & 1.078 & 0.116 \\
\hline
\end{tabular}

Table 1: Firm-level skill intensity and total factor productivity (TFP) by import status of firm.

The table shows the number of observations; means and standard deviations of firm-level log skill intensity of production (defined as non-blue-collar employment/bluecollar employment) and mean TFP (relative to the 4-digit-industry-year average) for the sample of French manufacturing firms by year. "Non-importers" includes firms that do not import in a given year. "Importers skill-abundant countries" includes firms that exclusively import from countries with more than 95 percent of the French level of secondary schooling. "Importers labor-abundant \& skill-abundant of countries" includes firms that import from both countries with less than and more than 95 percent of the French level of secondary schooling. 


\subsection{Decomposing changes in skill intensity}

Finally, in Table 2 we report the results of decomposing the aggregate change in log skill intensity between 1996 and 2007 into between and within-firm changes. We use firm-level employment shares as weights. As can be seen from the first row, overall skill intensity in French manufacturing increased by around 8 percentage points during this period. ${ }^{35}$ Within-firm changes accounted for an 18-percentage-point increase, but reallocation towards more labor-intensive firms mitigated the within-firm change by around 7 percentage points and exit of skill-intensive firms reduced the aggregate effect by another 3 percentage points.

In the other columns we further decompose the change in skill intensity into contributions stemming from non-importers; importers from skill-abundant countries; importers from both labor-abundant and skill-abundant locations and exclusive importers from labor-abundant countries (a marginal category, which we add for completeness). Importers from both sets of locations accounted for almost 40 percent $(0.37=0.029 / 0.078)$ of the total increase in skill intensity. Moreover, for importers from both sets of countries increases in firm-level skill intensity accounted for the bulk of the increase in aggregate skill intensity: within-firm changes lead to a 9-percentagepoint increase in overall skill intensity, while entry of less skill-intensive and exit of more skillintensive firms reduced the total effect of importing from this category on aggregate skill intensity to 2.9 percentage points. Exclusive importers from the set of skill-abundant locations also contributed to a 2.8 percent increase in total skill intensity. However, for these firms within-firm changes in skill intensity were zero, and the increase is explained by relatively labor-intensive firms exiting from this category. In line with our model, many of these firms started to also import from labor-abundant countries and moved into the category of firms importing from both sets of locations. ${ }^{36}$

Overall, the take-home from this exercise is that: (i) importers from both sets of locations accounted for around 40 percent of the increase in aggregate skill intensity in French manufacturing; (ii) all the increment in the skill intensity of these firms happened within firms, while reallocation towards more labor-intensive firms mitigated the impact of importing on aggregate skill intensity. We will thus focus mostly on the intensive margin when looking at the causal impact of offshoring on domestic skill intensity.

\footnotetext{
${ }^{35}$ The exact number is $7.8 \log$ points. This does not correspond exactly to the $10 \log$ points mentioned above because the log of the sum does not equal the sum of the logs.

${ }^{36}$ According to the decomposition also non-importers experienced a significant within-firm increase in skill intensity. This is not visible in Figure 3 or Table 1 . The discrepancy is due to the fact that the decomposition uses employment shares as weights, while Figure 3 and Table 1 present arithmetic averages for each category. Within-firm skill upgrading of non-importers is a feature that is not explained by our model.
} 


\begin{tabular}{rrrrrrr}
\hline \hline & total & within & between & entry & exit & firms \\
\hline all firms & 0.078 & 0.178 & -0.072 & -0.001 & -0.027 & 101,558 \\
non-importers & 0.020 & 0.058 & -0.016 & -0.027 & 0.005 & 67,084 \\
importers skill-abundant c. & 0.028 & 0.007 & -0.019 & -0.042 & 0.082 & 19,392 \\
importers labor- \& skill-abundant c. & 0.029 & 0.093 & 0.001 & -0.010 & -0.055 & 13,135 \\
importers labor-abundant c. & 0.001 & 0.000 & 0.000 & -0.002 & 0.002 & 1,947 \\
\hline \hline
\end{tabular}

Table 2: Decomposition of aggregate change in skill intensity.

The table shows a decomposition of changes in log skill intensity in French manufacturing into within and between firm changes from 1996 to 2007 using employment shares as weights. The decomposition is computed for each of the following categories: "Non-importers" includes firms that do not import throughout the period. "Importers skill-abundant countries" includes firms that exclusively import from countries with more than 95 percent of the French level of secondary schooling. "Importers labor- \& skill-abundant countries" includes firms that import from both countries with less and more than 95 percent of the French level of secondary schooling. "Importers labor-abundant countries" includes firms that exclusively import from countries with less than 95 percent of the French level of secondary schooling. "Entry" into a category is defined as firms that did not belong to a given category in 1996 and where present in the category in 2007, while "exit" from a category occurs if firms belonged to a given category in 1996 but not in 2007 .

\section{$5 \quad$ Regression-based Evidence}

In this section we present formal econometric evidence for Predictions 1-4 derived from our model.

\subsection{Sourcing patterns and productivity}

We first test the empirical predictions relating to the types of offshored inputs and the characteristics of the sourcing locations. We think of France as being moderately skill abundant: most countries are more labor abundant than France, but some countries are even more skill abundant. Since our predictions on sourcing patterns for labor-abundant compared to skill-abundant countries point in opposite directions, we split the sample by skill abundance and run separate regressions for each set of countries.

Prediction 1: According to Prediction 1, when considering importers from labor-abundant countries, the value of imports of relatively skill-intensive products should be larger for more productive firms. When considering instead importers from skill-abundant countries, the value of imports of relatively labor-intensive products should be larger for more productive firms. ${ }^{37}$ To test this hypothesis, we run the following regression specification separately for importers from

\footnotetext{
${ }^{37}$ Ideally, to estimate the extensive-margin decision to import, we would use a discrete import choice model, including all zero observations by firm-product-country-year. However, due to the curse of dimensionality, we can only consider observations with positive import values.
} 
labor-abundant and skill-abundant countries: ${ }^{38}$

$$
\begin{aligned}
\log (\text { import value })_{f, p, n, t} & =\beta_{1} \log (\gamma)_{f, 0} \times z_{p}+\beta_{2} \log (\gamma)_{f, 0}+\beta_{3} z_{p}+ \\
& +\beta_{4} X_{f, t}+\delta_{n, t}+\delta_{f, t}+\delta_{p, t}+\epsilon_{f, p, c, t}
\end{aligned}
$$

where $f$ denotes firms, $p$ denotes products, $n$ denotes sourcing locations and $t$ denotes years. $\log (\gamma)_{f, 0}$ is $(\log )$ TFP in the first period the firm appears in the sample and $z_{p}$ is the skill intensity of product $p$. The regressions always include country-year fixed effects $\left(\delta_{n, t}\right)$ that control for source-country-specific omitted variables (e.g. distance, market size, country-specific supply shocks). In some specifications we add the vector $X_{f, t}$, which includes employment, the capitallabor ratio and the value of exports (all in logs) to account for covariates that correlate both with TFP and imports. ${ }^{39}$ In further specifications we also add one by one firm-time $\left(\delta_{f, t}\right)$ and product-time $\left(\delta_{p, t}\right)$ fixed effects, which control for firm-specific (e.g., TFP) and product-specific shocks (e.g., product-level skill intensity). ${ }^{40}$ Since the main variable of interest, $\log (\gamma)_{f, 0} \times z_{p}$, varies at the firm level, we always cluster standard errors at this level.

For imports from labor-abundant countries, we expect the interaction term between productlevel skill intensity and firm-level TFP, $\beta_{1}$, to be positive. Moreover, we expect the coefficient on skill intensity, $\beta_{3}$, to be negative, since the comparative advantage of these countries is in laborintensive sectors. For imports from skill-abundant countries, we expect instead the coefficient of the interaction term, $\beta_{1}$, to be negative, while the coefficient of skill intensity, $\beta_{3}$, should be positive.

We report the results for the set of labor-abundant countries in columns (1)-(4) of Table 3. In line with the model, the interaction term between product skill intensity and TFP is always

\footnotetext{
${ }^{38}$ We have obtained similar results when pooling across all countries and interacting the coefficients of interest with dummies for the set of labor abundant and skill abundant locations. These results are available upon request.

${ }^{39}$ These variables proxy for factors outside of our model that impact on firms' unit costs and thus on their import decisions. We control for exports to account for potential complementarities between import and export decisions; for employment to control for increasing returns; and for capital intensity as an additional determinant of unit costs.

${ }^{40}$ Denote deviations from the country-year average with $\widetilde{x}_{f, p, n, t} \equiv x_{f, p, n, t}-\bar{x}_{n, t}$. Taking differences across two products imported by the same firm $f$ from the same location $n$ to eliminate $\delta_{f, t}$ and denoting differences across products with $\Delta_{p}$ and taking differences across two firms that import the same products $p$ and $p^{\prime}$ from a given location $n$ to eliminate $\delta_{p, t}$ :

$$
\Delta_{f} \Delta_{p} \log (\text { import value })_{f, p, n, t}=\beta_{1} \Delta_{f} \log \left(\gamma_{f, 0}\right) \Delta_{p} z_{p}+\Delta_{f} \Delta_{p} \widetilde{\epsilon}_{f, p, n, t}
$$

This specification with country-year, firm-year, and product-year fixed effect identifies the coefficient $\beta_{1}$ by comparing the import value of a skill-intensive to the one of a labor-intensive product for a firm with high productivity relative to one with low productivity from a given country. The more productive firm should import a larger value of the skill-intensive relative to the labor-intensive product from the same location compared to the less productive firm.
} 
positive and highly significant, while the coefficient of product-level skill intensity is negative. The outcomes for the set of skill-abundant countries are reported in columns (5)-(8). As predicted by our theory, the interaction term between skill intensity and $\log (T F P)_{f, 0}$ is in this case negative and highly significant, while the coefficient on skill intensity is positive.

Regarding the economic magnitudes of the coefficients, our most stringent specification in column (4) suggests that moving from the the 25th percentile of TFP to the 75 th percentile raises the import value for a product at the 75th percentile of skill intensity by around 20 percent in comparison with one at the 25 th percentile of skill intensity. ${ }^{41}$ Similarly, from column (8), moving from the 25 th percentile of TFP to the 75 th percentile, reduces the import value for a product at the 75 th percentile of skill intensity by around 52 percent in comparison with one at the 25 th percentile of skill intensity. ${ }^{42}$

In Appendix Table A-5 we provide evidence for the closely related prediction that more productive importers should have a larger variation in the skill intensities of their imported products compared to less productive ones. This follows from the model since more productive firms source a larger range of inputs from each set of locations. ${ }^{43}$

Prediction 2: For firms offshoring to the set of labor-abundant countries, more productive firms should have a larger import value from relatively more skill-abundant locations among them. (The symmetric statement applies to firms offshoring to skill-abundant countries.) This is driven by firms importing more skill-intensive (labor-intensive) products from these locations. To test this prediction, we modify our regression specification as follows:

$$
\begin{aligned}
\log (\text { import value })_{f, p, n, t} & =\beta_{1} \log (\gamma)_{f, 0} \times H_{n} / L_{n}+\beta_{2} \log (\gamma)_{f, 0}+\beta_{3} H_{n} / L_{n}+ \\
& +\beta_{4} X_{f, t}+\delta_{c, t}+\delta_{f, t}+\delta_{p, t}+\epsilon_{f, p, n, t}
\end{aligned}
$$

where $H_{n} / L_{n}$ is the skill abundance (measured in terms of years of secondary schooling) of country $n$ relative to France. The main coefficient of interest is $\beta_{1}$, the interaction term between firm-level TFP and country-level skill abundance. We expect this coefficient to be positive when conditioning on the set of labor-abundant countries and negative when conditioning on the set

\footnotetext{
${ }^{41}$ The skill intensity of a product at the 75 th percentile is 0.4 ; the skill intensity of a product at the 25 th percentile is around $0.2 ; \log (\mathrm{TFP})$ at the 75 th percentile is $4.21, \log$ TFP at the 25 th percentile is 3.36 . Thus, we have that $20 \approx 100 *\{\exp [1.038 *(0.4-0.2) *(4.21-3.36)]-1\}$.

${ }^{42} 52 \approx 100 *\{\exp [-5.628 *(0.4-0.2) *(4.21-3.36)]-1\}$.

${ }^{43}$ For each firm and location, we compute the (unweighted) population standard deviation of the skill intensity of the sourced inputs and regress it on firm-level TFP (controlling for the number of inputs to avoid picking up a mechanical effect). We present separate regressions for the set of labor-abundant and skill-abundant countries.
} 


\begin{tabular}{|c|c|c|c|c|c|c|c|c|}
\hline \multicolumn{9}{|c|}{ dependent variable is $\log (\text { imports })_{f, p, c, t}$} \\
\hline & $(1)$ & $(2$ & $(3)$ & $(4)$ & $(5)$ & $(6)$ & $(7)$ & $(8)$ \\
\hline $\log (\mathbf{T F P})_{f, 0} \times$ & $1.187 * * *$ & $0.791 * *$ & $1.868 * * *$ & $1.038 * * *$ & $-1.697 * * *$ & $-1.913 * * *$ & $-5.577 * * *$ & $-5.628 * * *$ \\
\hline skill intensity $p$ & $(0.331)$ & $(0.334)$ & $(0.301)$ & $(0.304)$ & $(0.261)$ & $(0.254)$ & $(0.097)$ & $(0.091)$ \\
\hline $\log (\mathrm{TFP})_{f, 0}$ & $\begin{array}{r}-0.1372 \\
(0.096)\end{array}$ & $\begin{array}{l}-0.131 \\
(0.095)\end{array}$ & & & $\begin{array}{c}1.209^{* * *} \\
(0.084)\end{array}$ & $\begin{array}{c}1.078^{* * *} \\
(0.087)\end{array}$ & & \\
\hline skill intensity $_{p}$ & $\begin{array}{c}-5.580^{* * *} \\
(1.350)\end{array}$ & $\begin{array}{c}-4.491^{* * *} \\
(1.332)\end{array}$ & $\begin{array}{c}-7.271^{* * *} \\
(1.248)\end{array}$ & & $\begin{array}{c}6.857^{* * *} \\
(1.022)\end{array}$ & $\begin{array}{c}7.433^{* * *} \\
(0.997)\end{array}$ & $\begin{array}{c}21.031 * * * \\
(0.371)\end{array}$ & \\
\hline $\log (\text { employees })_{f, t}$ & & $\begin{array}{l}-0.001 \\
(0.032)\end{array}$ & & & & $\begin{array}{c}0.063^{* * *} \\
(0.015)\end{array}$ & & \\
\hline $\log (\text { capital/labor })_{f, t}$ & & $\begin{array}{c}0.095^{* * * *} \\
(0.036)\end{array}$ & & & & $\begin{array}{c}0.124^{* * * *} \\
(0.014)\end{array}$ & & \\
\hline $\log (\text { exports })_{f, t}$ & & $\begin{array}{c}0.241^{* * *} \\
(0.017)\end{array}$ & & & & $\begin{array}{c}0.352^{* * *} \\
(0.007)\end{array}$ & & \\
\hline Observations & 558,000 & 558,000 & 550,434 & 544,475 & $3,086,696$ & $3,086,696$ & $3,076,941$ & $3,075,886$ \\
\hline R-squared & 0.037 & 0.061 & 0.268 & 0.391 & 0.031 & 0.077 & 0.233 & 0.330 \\
\hline Country-year FE & YES & YES & YES & YES & YES & YES & YES & YES \\
\hline Firm-year FE & $\mathrm{NO}$ & $\mathrm{NO}$ & YES & YES & $\mathrm{NO}$ & $\mathrm{NO}$ & YES & YES \\
\hline Product-year FE & $\mathrm{NO}$ & NO & $\mathrm{NO}$ & YES & NO & NO & NO & YES \\
\hline Cluster & Firm & Firm & Firm & Firm & Firm & Firm & Firm & Firm \\
\hline
\end{tabular}

Table 3: Sourcing, input skill intensity and productivity.

In columns (1)-(4) the dependent variable is log imports from labor-abundant countries at the firm-product-countryyear level. In columns (5)-(8) it is log imports from skill-abundant countries. We define countries with less than 95 percent of the French level of secondary schooling as labor abundant and the remaining countries as skill abundant. The main explanatory variable of interest is the interaction between product-level skill intensity (skill intensity ${ }_{p}$ ) and firm-level productivity computed with the Levinsohn-Petrin method $\left(\log (T F P)_{f, 0}\right)$. Other controls are (all at the firm level and in logs): the number of employees, the capital-labor ratio, the value of exports. Standard errors are clustered at the firm level.

\begin{tabular}{|c|c|c|c|c|c|c|c|c|}
\hline \multicolumn{9}{|c|}{ dependent variable is $\log (\text { imports })_{f, p, c, t}$} \\
\hline & $(1)$ & $(2$ & $(3)$ & $(4)$ & $(5)$ & $(6)$ & $(7)$ & $(8)$ \\
\hline $\log (\mathbf{T F P})_{f .0} \times$ & $0.317^{*}$ & $0.379 * *$ & $0.282^{* * *}$ & 0.154 & $-0.277^{*} * *$ & $-0.240 * * *$ & $-1.752 * * *$ & 0.007 \\
\hline sec. schooling $_{c}$ & $(0.183)$ & $(0.186)$ & $(0.092)$ & $(0.097)$ & $(0.050)$ & $(0.054)$ & $(0.027)$ & $(0.033)$ \\
\hline $\log (\mathrm{TFP})_{f, 0}$ & -0.053 & $-0.192^{* *}$ & & & $0.391 * * *$ & $0.200 * *$ & & \\
\hline & $(0.074)$ & $(0.083)$ & & & $(0.070)$ & $(0.080)$ & & \\
\hline $\log (\text { employees })_{f, t}$ & & -0.005 & & & & $0.104^{* * *}$ & & \\
\hline & & $(0.032)$ & & & & $(0.015)$ & & \\
\hline $\log (\text { capital/labor })_{f, t}$ & & $0.089^{* *}$ & & & & $0.148^{* * *}$ & & \\
\hline & & $(0.036)$ & & & & $(0.015)$ & & \\
\hline $\log (\text { exports })_{f, t}$ & & $0.231^{* * *}$ & & & & $0.358 * * *$ & & \\
\hline & & $(0.017)$ & & & & $(0.007)$ & & \\
\hline Observations & 572,678 & 572,678 & 565,188 & 559,022 & $3,117,767$ & $3,117,767$ & $3,109,836$ & $3,108,695$ \\
\hline R-squared & 0.036 & 0.057 & 0.277 & 0.393 & 0.013 & 0.067 & 0.238 & 0.348 \\
\hline Country-year FE & YES & YES & YES & YES & YES & YES & YES & YES \\
\hline Firm-year FE & $\mathrm{NO}$ & $\mathrm{NO}$ & YES & YES & $\mathrm{NO}$ & $\mathrm{NO}$ & YES & YES \\
\hline Product-year FE & $\mathrm{NO}$ & $\mathrm{NO}$ & $\mathrm{NO}$ & YES & NO & $\mathrm{NO}$ & $\mathrm{NO}$ & YES \\
\hline Cluster & Firm & Firm & Firm & Firm & Firm & Firm & Firm & Firm \\
\hline
\end{tabular}

Table 4: Sourcing, country skill abundance and productivity.

In columns (1)-(4) the dependent variable is log imports from labor-abundant countries at the firm-product-countryyear level. In columns (5)-(8) it is log imports from skill-abundant countries. We define countries with less than 95 percent of the French level of secondary schooling as labor abundant and the remaining countries as skill abundant. The main explanatory variable of interest is the interaction between country-level skill abundance (sec. schooling $\left.g_{c}\right)$ and firm-level productivity computed with the Levinsohn-Petrin method $\left(\log (T F P)_{f, 0}\right)$. Other controls are (all at the firm level and in logs): the number of employees, the capital-labor ratio, the value of exports. Standard errors are clustered at the firm level. 
of skill-abundant locations. We thus run separate regressions for each set of locations. ${ }^{44} \mathrm{We}$ always include country-year effects, $\delta_{n, t}$, to control for omitted variables that vary at this level. These fixed effects absorb $H_{n} / L_{n}$. In a second specification we also include the vector $X_{f, t}$ which consists of our set of firm-specific controls. In the remaining specifications we additionally add one by one firm-year $\left(\delta_{f, t}\right)$ and product-year $\left(\delta_{p, t}\right)$ fixed effects. The specifications without product-year fixed effects identify $\beta_{1}$ by using variation in import values across products, locations and firms. The specification with product-year fixed effects instead exploits variation in import values across firms and locations for a given product. According to our model, more productive importers from the set of labor-abundant countries should import from more skillabundant locations among them compared to less productive ones because they import a set of more skill-intensive products from them. Thus, we expect $\beta_{1}$ to be positive and significant in the specification without product-year fixed effects, as this coefficient will pick up variation in the set of imported products. Consequently, once we control for the identity of the product by including product-year fixed effects, we expect $\beta_{1}$ to become insignificant. ${ }^{45}$ We run regressions considering only positive import values. ${ }^{46}$ Again, since the variable of interest varies at the firm level, we cluster standard error at this level.

Results for the specification are reported in Table 4. In columns (1)-(4) we report results for labor-abundant countries and in columns (5)-(8) for skill-abundant ones. In line with the model, the interaction term between skill abundance and productivity is positive and significant in columns (1)-(3) and becomes insignificant in column (4), where we control for product-year fixed effects. The results in columns (5)-(8) are also consistent with our theory: the interaction term between schooling and productivity is negative and significant in columns (5)-(7) and becomes insignificant in column (8) when including product-year fixed effects.

In terms of economic magnitudes, according to the specification in column (3), moving from the the 25 th percentile of TFP to the 75 th percentile, the import value from a location at the 75th percentile of skill abundance increases by around 10 percent compared to one at the 25th

\footnotetext{
${ }^{44}$ Similar results are obtained when pooling across all countries and interacting the covariates with dummies for labor-abundant and skill-abundant locations.

${ }^{45}$ Denote deviations from the country-year average with $\widetilde{x}_{f, p, n, t} \equiv x_{f, p, n, t}-\bar{x}_{n, t}$. Taking differences across locations and firms to eliminate firm-year and product-year fixed effects, we obtain:

$$
\Delta_{f} \Delta_{n} \log (\text { imports })_{f, p, n, t}=\beta_{1} \Delta_{f} \log \left(\gamma_{f, 0}\right) \Delta_{n} H_{n} / L_{n}+\Delta_{f} \Delta_{n} \widetilde{\epsilon}_{f, p, n, t}
$$

Here $\beta_{1}$ is identified by comparing the import value of a given product for a high-productivity compared to a low-productivity firm from a more relative to a less skill abundant country.

${ }^{46}$ Because the regression coefficients will also pick up variation in import value across firms for a given set of locations (intensive margin), we report results for a dispersion measure in the skill abundance of sourcing locations (extensive margin) in the Appendix.
} 
percentile of skill abundance. ${ }^{47}$ Similarly, from column (7), moving from the 25 th percentile of TFP to the 75th percentile, the import value from a country at the 75 th percentile of skill abundance decreases by around 23.5 percent compared to one at the 25 th percentile of skill abundance. $^{48}$

In Appendix Table A-5 we provide evidence for the closely related prediction that more productive importers should have a larger variation in the skill abundance of their sourcing locations compared to less productive ones. This follows from the model since more productive firms source from a larger range of locations within each set of factor-abundant countries. ${ }^{49}$

\subsection{Offshoring and domestic skill intensity}

We now turn to testing the predictions relating the skill intensity of production in France to imports from labor-abundant and skill-abundant countries. Predictions 3 (import status) and 4 (import intensity) state that importing from the set of labor-abundant countries increases a firm's domestic skill intensity, whereas importing from skill-abundant countries reduces it. The corresponding regression specification is:

$$
\begin{aligned}
\log \left({\text { skillintensity })_{f, t}}\right. & =\beta_{0}+\beta_{1} \text { imports labor-abundant countries }_{f, t}+ \\
& +\beta_{2} \text { imports skill-abundant countries }_{f, t}+\delta_{s}+\delta_{f}+\delta_{t}+\epsilon_{f, t}
\end{aligned}
$$

where imports labor-abundant countries ${ }_{f, t}$ is either a dummy equal to one if the firm imports from the set of labor-abundant countries in year $t$ (Prediction 3) or the firm-level import intensity, measured as the ratio of imports from labor-abundant countries relative to total sales (Prediction 4). ${ }^{50}$ Similarly, imports skill-abundant countries $_{f, t}$ is either a dummy for importing from the set of skill-abundant countries, or the ratio of imports from skill-abundant countries to total sales. We also include either sector fixed effect for the firm's primary activity at the 4-digit level $\left(\delta_{s}\right)$ or firm fixed effects $\left(\delta_{f}\right)$ and in some specification also year fixed effects $\left(\delta_{t}\right)$. The sector fixed effects control for sector-specific differences in average skill and import intensity across firms, while the

\footnotetext{
${ }^{47}$ For the set of labor-abundant locations, the skill abundance at the 75 th percentile is 0.58 ; the skill abundance of a country at the 25 th percentile is around 0.23 ; $\log$ (TFP) at the 75 th percentile is $4.21, \log$ TFP at the 25 th percentile is 3.36 . Thus, we have that $10 \approx 100 *\{\exp [0.282 *(0.58-0.23) *(4.21-3.36)]-1\}$.

${ }^{48}$ For the set of skill-abundant locations, the skill abundance of a country at the 75 th percentile is 1.09 and the skill abundance of a country at the 25 th percentile is $0.86 .23 .5 \approx 100 *\{\exp [-1.752 *(1.09-0.86) *(4.21-3.36)]-1\}$.

${ }^{49}$ For each firm, we compute the (unweigthed) population standard deviation of the skill abundance of the sourcing locations and regress it on firm-level TFP (controlling for the number of sourcing locations to avoid picking up a mechanical effect). We present separate regressions for the set of labor-abundant and skill-abundant countries.

${ }^{50}$ We normalize imports by sales instead of total variable costs since we cannot measure the latter in our data.
} 
firm fixed effects identify within-firm changes in skill intensity and importing from both sets of countries. When including year fixed effects we identify the impact of importing on domestic skill intensity as deviations from the trend in importing and skill intensity that is visible in Figure 3 . To make the standard errors robust to autocorrelation in the residuals we always cluster standard errors at the firm level.

Prediction 3: We present results for Prediction 3 in the first four columns of Table 5. Here, we consider the full sample of firms, including non-importers. In columns (1) and (2), we report specifications including 4-digit sector fixed effects, using the cross-sectional variation to identify coefficients. Importers from labor-abundant countries are around 23 percent ${ }^{51}$ more skill-intensive in their domestic production than non-importers; this effect is statistically highly significant and robust to controlling for year fixed effects in column (2). Importers from skill-abundant countries are instead somewhat less skill-intensive than non-importers (around 3.3 percent (column (1)). In columns (3) and (4), we report results including firm fixed effects, thereby identifying the effects using within-firm changes in import status: the result in column (4), which also controls for year fixed effects, indicates that starting to import from labor-abundant countries is associated with a 4-percent increase in skill intensity, while starting to import from skill-abundant countries is associated with a 1.2-percent decrease.

Prediction 4: We now consider the import intensity of firms as our explanatory variable of interest. We always include firm fixed effects in these specifications. Results are reported in columns (5)-(8) of Table 5. In columns (5) and (6) we include all firms in the sample (including non-importers), while in columns (7) and (8) we restrict the sample to importers from both sets of countries, which - as explained below - is the sample considered in our instrumentalvariable regressions. Note that in this case we identify the impact of changes in imports/sales from labor-abundant and skill-abundant locations within a given firm. Columns (6) and (8) additionally include year fixed effects. Columns (5) and (6) imply that a one-percentage point increase in imports to sales from labor-abundant countries increases domestic skill intensity by 0.25 to 0.3 percent. This effect stands in contrast to the impact of importing from skill-abundant countries: a one-unit increase in the imports-to-sales ratio from these countries reduces firmlevel skill intensity slightly. However, this effect is not statistically significant. Finally, the point estimates for the sample of importers from both sets of countries (columns (7)-(8)) are very similar to those obtained for the full sample of firms, confirming that we can focus on these firms when considering the causal impact of importing on domestic skill intensity in the instrumental-variable

\footnotetext{
${ }^{51} 22.7=100 *(\exp (0.2047)-1),($ column $(1))$.
} 
regressions reported below.

In Appendix Table A-6, we present results for the same specifications but additionally include a number of firm-level controls (TFP, exports, firm size and capital intensity) that could be confounds with importing. ${ }^{52}$ We show that our results are robust to including them in the regressions.

Finally, in Appendix Tables A-7 and A-8 we control for sector-specific import competition. Import competition may potentially be correlated with offshoring and, as shown by Mion and Zhu (2013), also induces firms to increase their domestic skill intensities. We pursue two alternative strategies to address this concern. In Table A-7 we add a measure of import competition in the firms' output market as an additional control variable. It is constructed as 4-digit sectoral imports relative to sectoral absorption in each firm's main activity. We find that the point estimates and the statistical significance of the offshoring variables remain unaffected, while the measure of import competition is mostly insignificant. In Table A-8 we include 4-digit-sectoryear fixed effects, which absorb any unobserved (demand or supply) shocks to the firms' output sector. Again, the point estimates and the significance of the offshoring variables are virtually unaffected.

To sum up, and as predicted by our theory, importing from labor-abundant countries is associated with large increases in the skill intensity of production in France, while importing from skill-abundant is associated with a moderate reduction of this variable. ${ }^{53}$

\subsection{IV estimates}

We have already provided detailed evidence that imports from labor-abundant countries are concentrated in labor-intensive inputs and thus substitute for domestic unskilled labor. Still, one may argue that the OLS regressions presented in Table 5 are not causal. Import intensity may potentially be endogenous to domestic skill intensity because of omitted variables.

We therefore use foreign supply-shock-based instruments to obtain exogenous variation in import supply from both sets of locations. These instruments use exogenous within-firm variation

\footnotetext{
${ }^{52}$ The rationale for including exports in the specification is to control for the exporting-skill-upgrading channel (e.g., Bustos, 2011). We include $\log (T F P)$ to control for technology-based explanations of skill-upgrading (Acemoglu, 1998). We include the capital-labor ratio to control for capital-skill complementarity (Krusell et al., 2000) and the number of employees to control for skill-biased scale effects (e.g., Burstein and Vogel, 2016).

${ }^{53}$ In unreported regressions we have also regressed the employment of skilled and unskilled workers separately on imports relative to sales from labor-abundant and skill-abundant countries. We find that that firms which increase imports from labor-abundant countries reduce blue-collar employment and increase employment of white-collar workers, while the opposite happens for firms that increase imports from skill-abundant countries. Moreover, as our model suggests, these firms simultaneously increase their sales.
} 
in import intensity over time and we thus need to restrict the sample to those firms that are continuous importers both from labor-abundant and from skill-abundant locations. We report results with firm fixed effects, since the instruments are plausibly exogenous only conditional on time-invariant firm-specific factors (the import shares at the country-product level in the initial period, which imply a differential sensitivity to country-product-specific supply shocks). According to our theory, a positive supply shock from labor-abundant countries (which reduces $\tau_{n^{\prime} n}$ ) reduces the firm's marginal cost and thus increases $z_{n}^{-}$and lowers $z_{n}^{+}$, increasing imports/sales from both sets of locations. A similar effect occurs for a reduction in $\tau_{n^{\prime} n}$ from skill-abundant countries. These effects are captured by the first-stage regressions, which relate imports/sales from each set of locations to both supply shocks. 


\begin{tabular}{|c|c|c|c|c|c|c|c|c|}
\hline \multicolumn{9}{|c|}{ dependent variable is $\log$ (skill intensity $)_{f t}$} \\
\hline & (1) & $(2)$ & $(3)$ & $(4)$ & $(5)$ & (6) & (7) & (8) \\
\hline import status & $0.2047^{* * *}$ & $0.1996^{* * *}$ & $0.0567 * * *$ & $0.0388^{* * *}$ & & & & \\
\hline labor-abundant $\mathbf{c} \cdot f, t$ & $(0.009)$ & $(0.009)$ & $(0.004)$ & $(0.004)$ & & & & \\
\hline import status & $-0.0328^{* * *}$ & $-0.0349 * * *$ & 0.0012 & $-0.0124^{* * *}$ & & & & \\
\hline skill-abundant $\mathbf{c} \cdot f, t$ & $(0.006)$ & $(0.006)$ & $(0.003)$ & $(0.003)$ & & & & \\
\hline imports/sales & & & & & $0.3008^{* * *}$ & $0.2500^{* * *}$ & $0.3909^{* * *}$ & $0.2152^{* *}$ \\
\hline labor-abundant $\mathbf{c} \cdot f, t$ & & & & & $(0.114)$ & $(0.096)$ & $(0.158)$ & $(0.099)$ \\
\hline imports/sales & & & & & -0.0048 & -0.0086 & -0.0141 & -0.0231 \\
\hline skill-abundant $\mathbf{c} \cdot f, t$ & & & & & $(0.006)$ & $(0.006)$ & $(0.018)$ & $(0.016)$ \\
\hline Observations & 646,920 & 646,920 & 646,920 & 646,920 & 646,920 & 646,920 & 55,719 & 55,719 \\
\hline Firms & 104,036 & 104,036 & 104,036 & 104,036 & 104,036 & 104,036 & 12,714 & 12,714 \\
\hline 4-digit sector FE & YES & YES & NO & NO & NO & NO & NO & NO \\
\hline Firm FE & NO & NO & YES & YES & YES & YES & YES & YES \\
\hline Year FE & NO & YES & $\mathrm{NO}$ & YES & $\mathrm{NO}$ & YES & NO & YES \\
\hline Cluster & Firm & Firm & Firm & Firm & Firm & Firm & Firm & Firm \\
\hline Sample & All & All & All & All & All & All & $\begin{array}{l}\text { Importers } \\
\text { both }\end{array}$ & $\begin{array}{c}\text { Importers } \\
\text { both }\end{array}$ \\
\hline
\end{tabular}

Table 5: Skill intensity of domestic production and importing from labor-abundant and skill-abundant countries (extensive and intensive margin).

The dependent variable is the firm-level $(\log )$ skill intensity of production, defined as the ratio of non-production workers to production workers. We consider countries with less than 95 percent of the French level of secondary schooling as labor abundant and other countries as skill abundant. In columns (1)-(4), the main explanatory variable of interest is a dummy for importing from the set of labor-abundant countries (import status labor-abundant c.) and a dummy for importing from the set of skill-abundant countries (import status skill-abundant c.). In columns (5)-(8), the main explanatory variable of interest is the ratio of imports from set of labor-abundant countries relative to sales (import/sales labor-abundant c.) and the ratio of imports from the set of skill-abundant countries relative to sales (imports/sales skill-abundant c.). Standard errors are clustered at the firm level. 


\begin{tabular}{|c|c|c|c|c|c|c|c|}
\hline \multirow[t]{2}{*}{ First Stage: } & \multicolumn{2}{|c|}{$\begin{array}{l}\text { Dep. var.: imports/sales } \\
\text { labor-abundant c. } f, t\end{array}$} & \multicolumn{2}{|c|}{$\begin{array}{l}\text { Dep. var.: imports/sales } \\
\text { skill-abundant c. } f, t\end{array}$} & \multirow[t]{2}{*}{ Second Stage: } & \multicolumn{2}{|c|}{ Dep. var.: $\log (\text { skill intensity })_{f, t}$} \\
\hline & (1) & $(2)$ & $(3)$ & $(4)$ & & $(5)$ & $(6)$ \\
\hline IV Supply Shock & $0.0101^{* * *}$ & $0.0029 *$ & $0.0026^{* * *}$ & $0.0027^{*}$ & & & \\
\hline labor-abundant $\mathbf{c} \cdot f, t$ & $(0.001)$ & $(0.002)$ & $(0.001)$ & $(0.002)$ & & & \\
\hline IV Supply Shock & $0.0111^{* * *}$ & $0.0064^{* * *}$ & $-0.0053^{*}$ & $0.0066^{* *}$ & & & \\
\hline skill-abundant $\mathbf{c} \cdot f, t$ & $(0.003)$ & $(0.002)$ & $(0.003)$ & $(0.003)$ & & & \\
\hline imports/sales & & & & & & $5.8154^{* * *}$ & $5.5135^{* *}$ \\
\hline labor-abundant $\mathbf{c} \cdot f, t$ & & & & & & $(2.071)$ & $(2.760)$ \\
\hline imports/sales & & & & & & -1.7158 & $-4.2816^{*}$ \\
\hline skill-abundant $\mathbf{c} \cdot f, t$ & & & & & & $(5.807)$ & $(2.376)$ \\
\hline Observations & 55,719 & 55,719 & 55,719 & 55,719 & & 55,719 & 55,719 \\
\hline Firms & 12,714 & 12,714 & 12,714 & 12,714 & & 12,714 & 12,714 \\
\hline Firm FE & YES & YES & YES & YES & & YES & YES \\
\hline Year FE & NO & $\mathrm{NO}$ & YES & YES & & $\mathrm{NO}$ & YES \\
\hline Cluster & Firm & Firm & Firm & Firm & & Firm & Firm \\
\hline Sample & Importers & Importers & Importers & Importers & & Importers & Importers \\
\hline Sample & both & both & both & both & & both & both \\
\hline F-Statistic (Angrist-Pischke) & 16.45 & 12.34 & 15.32 & 11.57 & & & \\
\hline
\end{tabular}

Table 6: Skill intensity of domestic production and importing from labor-abundant and skill-abundant countries (IV estimates).

The dependent variable in the second-stage regression (columns (5)-(6)) is the firm-level (log) skill intensity of production, defined as the ratio of non-production

workers to production workers. The main explanatory variable of interest is the ratio of imports from set of labor-abundant countries relative to sales (import/sales labor-abundant c.) and the ratio of imports from the set of skill-abundant countries relative to sales (imports/sales skill-abundant c.). We consider imports from countries with less than 95 percent of the French level of secondary schooling as labor abundant and the remaining countries as skill abundant. Both imports/sales from labor-abundant and skill-abundant countries are considered endogenous. Instruments are constructed from foreign supply-shocks (see data section for an explanation). First-stage regressions are reported in columns (1)-(4). We present Angrist-Pischke F-statistics for the joint significance of instruments with multiple endogenous variables. Standard errors are clustered at the firm level. 
In the second stage, the shock-induced changes in imports/sales from labor-abundant and skillabundant countries then impact on domestic skill intensity.

We present the results for the IV regressions in Table 6. In the first-stage regressions - reported in columns (1) and (2) for the specification without year fixed effects and in columns (3) and (4) for the one including them - we find that the shocks have the expected signs: a positive supply shock from labor-abundant countries increases import intensity from this set of locations, and similarly for skill-abundant countries. These effects are highly statistically significant. Moreover, a positive supply shock from labor-abundant countries also increases import intensity from skillabundant ones, and vice versa. The Angrist-Pischke F-statistic is always above 15 for the firststage regressions with imports/sales from labor-abundant countries as dependent variable and above 11 when imports/sales from skill-abundant locations is instrumented. This indicates that both instruments provide independent exogenous variation and are sufficiently strong. ${ }^{54}$

We now turn to the second-stage results for the causal impact of supply-shock-induced increases in imported intensity on domestic skill intensity, which are reported in columns (5) and (6). The point estimate for the coefficient for importing from labor-abundant countries is now 5.51 to 5.81 and statistically highly significant. ${ }^{55}$ By contrast, the point estimate for the impact of offshoring to skill abundant countries is between -1.7 and -4.28 and only marginally significant. The large increase in the magnitude of the coefficients compared to the OLS regression results (compare with columns (7) and (8) of Table 4) deserves a more detailed discussion.

The most plausible reason why the IV coefficients are much larger than the OLS coefficients is heterogeneity in treatment effects. In their presence, the IV estimate measures the causal impact of offshoring on those firms whose import behavior is changed by the foreign supply shocks (compliers). By contrast, the OLS coefficient measures the average treatment effect plus a potential endogeneity bias (Angrist and Pischke, 2009). If the impact of offshoring on domestic skill intensity is particularly large for compliers (or when the endogeneity bias is negative), the IV estimate will be significantly larger than the OLS coefficient. Identifying compliers is not straightforward (see Angrist and Pischke, 2009, chapter 4), but we can investigate for which type of firms and products the foreign supply shocks were particularly large. Equation (8) implies that the instrument is given by the interaction of initial-period import shares with the growth

\footnotetext{
${ }^{54}$ Moreover, note that just identified IV is median-unbiased (see, e.g., Angrist and Pischke, 2008, Chapter 4), so that even in the presence of weak instruments the IV estimates would still be consistent but their standard errors would become very large.

${ }^{55}$ Hummels et al. (2014) find a very similar increase in the order of magnitude of their point estimates compared to the OLS estimates when instrumenting for the effect of offshoring on wages of Danish workers using foreign supply shocks.
} 
rate of foreign supply shocks. We see from the last column of Table 1 that the firms importing from both sets of locations in the beginning of the sample period were more productive than those importing from these locations at the end of the sample period. Moreover, to check if these firms imported different products compared to the average importer from both sets of locations, we regress product-level import shares of importers from both locations on interactions of skill intensity and a dummy for the first year the firm is in the sample. We find that - as in the model - importers from both locations importing in the beginning of the sample period sourced on average more skill-intensive products (see Appendix Table A-7). Finally, we also regress the growth rates of product-level foreign supply shocks from labor-abundant locations on product-level skill intensity and find larger effects for more skill-intensive products (Appendix Table A-7). Thus, those importers from both sets of locations which increased their imports most in response to foreign supply shocks were high-productivity firms that increased imports because they raised the import values of relatively skill-intensive products substantially. In response, they also increased their domestic skill intensity by more compared to the average importer from both sets of locations. This is consistent with the results from Section 2.4, where we showed that those firms responding most to reductions in offshoring costs to labor-abundant countries in terms of domestic skill intensity are (i) high-productivity firms, (ii) in particular when cost reductions are stronger for more skill-intensive products.

Another potential explanation for the smaller OLS coefficients is an omitted variable that correlates negatively with offshoring and positively with domestic skill intensity. Automatization and offshoring to labor-abundant countries might be substitutes at the firm level: firms may reduce costs either by offshoring labor-intensive inputs or by using new technologies that substitute machines for labor-intensive tasks. Goos et al. (2014) show that tasks amenable to offshoring are usually also routine and can thus be automatized relatively easily. This mechanism would introduce a negative correlation between offshoring and (unobserved) automatization, both of which lead to an increase in skill intensity of domestic production. Finally, the IV coefficients might be larger in magnitude than the OLS coefficients if the exclusion restriction that the instrument affects skill intensity exclusively via offshoring is violated. In particular, one may be concerned about import competition in final-goods markets. Bloom, Draca and Van Reenen (2015) find that harsher import competition in final goods from low-wage countries induces European firms to innovate more and to upgrade the skill composition of their domestic labor force. However, our instruments are based on supply shocks in the input sectors and do not capture supply shocks 
in the market for firms' final output, so a violation of the exclusion restriction is not a concern. ${ }^{56}$

The IV estimates imply large causal effects of increasing import intensity from labor-abundant countries on domestic skill intensity for compliers. According to Table 2, firms importing from both sets of locations account for the bulk of importers from labor-abundant countries and all of the within-firm changes in skill intensity for importers. For firms importing from both sets of countries, the mean of skill intensity changed by around 8.1 log points between 1996 and 2007 (from -0.296 to -0.215 , see Table 1 ). We use the point estimate for the effect of importing from labor-abundant countries from Table 6 , column 6 together with the fact that for firms importing from both sets of locations average imports/sales from labor-abundant countries increased from 0.053 to 0.07 from 1996 to 2007 . The predicted increase in domestic skill intensity for compliers is then given by $5.51^{*}(0.07-0.053) * 100=9.3 \log$ points. ${ }^{57}$ By contrast, imports/sales from skill-abundant countries stayed roughly constant at around 0.14 , so the predicted change in skill intensity due to offshoring to skill-abundant countries is zero for compliers. Thus, reduced offshoring costs to labor-abundant countries can explain all the observed within-firm increase in the skill intensity of compliers. Of course, the within-firm estimation strategy does not allow us to assess the role of importing in reallocation towards more labor-intensive firms, which according to Table 2 has mitigated the aggregate change in domestic skill intensity compared to the large within-firm increase.

\section{Conclusions}

This paper develops a factor-proportions theory of offshoring with heterogeneous firms. From the perspective of France, a relatively skill-abundant country, sufficiently productive firms selfselect into offshoring skill-intensive inputs to skill-abundant countries, while firms with even higher productivity also offshore labor-intensive inputs to labor-abundant countries. This leads to within-industry variation in the skill intensity of production of firms. A reduction in offshoring costs to labor-abundant countries implies an increase in the skill intensity of domestic production, as the marginal input that can be profitably offshored becomes more skill intensive. Our theory generates precise predictions on firm-level import patterns: first, more productive firms offshoring

\footnotetext{
${ }^{56}$ In unreported regressions, we have reestimated the IV specifications including additional sector-year fixed effects, thus controlling for changes in import competition. Our coefficients of interest remained qualitatively unaffected but the estimates became less precise.

${ }^{57}$ In line with the observation that compliers are high-productivity importers from both sets of locations, this number happens to coincide exactly with the actual employment-weighted within-firm change in skill intensity for importers from both sets of countries (see Table 2).
} 
to skill-abundant (labor-abundant) countries will source relatively more labor-intensive (skillintensive) marginal inputs than less productive ones; second, out of the set of skill-abundant (labor-abundant) countries, more productive firms will source from the relatively less (more) skill-abundant ones.

Using a quasi-exhaustive panel of French manufacturing firms we show that the predicted offshoring patterns are strongly supported by the data. Finally, we use a foreign-supply-shockbased instrument to identify the causal impact of reduced offshoring costs to labor-abundant countries on the increase in the domestic skill intensity of French manufacturing firms. We find that the bulk of the observed within-firm increase in the domestic skill intensity of firms importing from labor-abundant countries can be explained by increased offshoring to these countries.

This work is a first step in an attempt to understand how factor-proportions forces operate at the within-industry and within-firm level. Our empirical analysis has provided evidence that Heckscher-Ohlin-driven offshoring can be a powerful source of changes in the relative demand for skill within firms. An interesting avenue for future research is to develop a more structural version of our model in order to better understand its quantitative implications in general equilibrium.

\section{References}

[1] Daron Acemoglu, 1998. "Why do new technologies complement skills? Directed technical change and wage inequality," Quarterly Journal of Economics, 113(4), 1055-1089.

[2] Joshua Angrist and Joern-Steffen Pischke, 2009, Mostly Harmless Econometrics, Princeton University Press.

[3] Pol Antràs, 2003. "Firms, Contracts, And Trade Structure," Quarterly Journal of Economics, 118(4), 1375-1418.

[4] Pol Antràs, and Elhanan Helpman, 2004. "Global Sourcing," Journal of Political Economy, $112(3)$.

[5] Pol Antràs, Teresa Fort and Felix Tintelnot (2017). "The Margins of Global Sourcing: Theory and Evidence from U.S. Firms," American Economic Review, 107 (9), 2514-2564

[6] David Autor, David Dorn, and Gordon H. Hanson, 2013. "The China syndrome: local market effects of import competition in the U.S.," American Economic Review, 103(6), 2121-2168.

[7] David Autor, David Dorn, Gordon H. Hanson, and Jae Song, 2014. "Trade Adjustment: Worker-level Evidence," Quarterly Journal of Economics, 129(4), 1799-1860.

[8] Robert Barro and Jong-Wha Lee, 2013. "A new data set of educational attainment in the world, 1950-2010," Journal of Development Economics, 104, 184-198.

[9] Eric J. Bartelsman and Wayne Gray, 1996. "The NBER Manufacturing Productivity Database," NBER Technical Working Paper 0205.

[10] Andrew B. Bernard, Stephen J. Redding and Peter K. Schott, 2011. "Multiproduct Firms and Trade Liberalization," Quarterly Journal of Economics, 126(3), 1271-1318. 
[11] Pierre Biscourp, and Francis Kramarz, 2007. "Employment, skill structure and international trade: Firm-level evidence for France," Journal of International Economics, 72(1), 22-51.

[12] Joaquin Blaum, Claire LeLarge, Michael Peters, 2018. "Firm Size and the Intensive Margin of Import Demand," Journal of International Economics, forthcoming.

[13] Joaquin Blaum, Claire LeLarge, Michael Peters, 2018. "The Gains from Input Trade With Heterogeneous Importers," American Economic Journal: Macroeconomics, 10 (4), 77-127.

[14] Nicolas Bloom, Mirko Draca and John Van Reenen, 2015. "Trade Induced Technical Change: The Impact of Chinese Imports on Innovation, Diffusion and Productivity," Review of Economic Studies, 83(1) 87-117.

[15] Harry Bowen, Edward Leamer and Leo Sveikauskas, 1987. "Multicountry, Multifactor Tests of the Factor Abundance Theory," American Economic Review, 77, 791-809.

[16] Ariel Burstein and Jonathan Vogel, 2016. "International Trade, Technology, and the Skill Premium," Journal of Political Economy, forthcoming.

[17] Paula Bustos, 2011. "Trade Liberalization, Exports and Technology Upgrading: Evidence on the Impact of MERCOSUR on Argentinean Firms," American Economic Review, 101 (1), 304-340.

[18] Pierre Cahuc, Fabien Postel-Vinay and Jean-Marc Robin, 2006. "Wage Bargaining with On-the-Job Search: Theory and Evidence," Econometrica, 74(2), 323-364.

[19] Lorenzo Caliendo, Ferdinando Monte and Esteban Rossi-Hansberg, 2015. "The Anatomy of French Production Hierarchies," Journal of Political Economy, 123 (4), 809-852.

[20] Juan Carluccio, Alejandro Cuñat, Harald Fadinger and Christian Fons-Rosen, 2015 "Offshoring and Skill-Upgrading in French Manufacturing: a Heckscher-Ohlin-Melitz View" CEPR Discussion Paper Nr. 10864.

[21] Juan Carluccio, Denis Fougère and Erwan Gautier, 2015 "Trade, Wages, and Collective Bargaining: Evidence from France" Economic Journal, 125(584), 803-837.

[22] Francesco Caselli and Wilbur Coleman, 2006. "The World Technology Frontier," American Economic Review, 96(3), 499-522.

[23] Gregory Corcos, Delphine Irac, Giordano Mion and Thierry Verdier, 2013. "The Determinants of Intra-Firm Trade," Review of Economics and Statistics, 95(3), 835-838.

[24] Matthieu Crozet and Federico Trionfetti, 2013. "Firm-level Comparative Advantage, " Journal of International Economics, 91(2), 321-328.

[25] Alejandro Cuñat and Harald Fadinger, 2018 "A Heckscher-Ohlin-Melitz Model of Exporting and Offshoring," in Wilhem Kohler and Erdal Yalcin, eds., Developments in Global Sourcing, MIT Press.

[26] Jonathan Eaton and Samuel Kortum, 2002. "Technology, Geography, and Trade, " Econometrica, 70(5), 1741-1779.

[27] Robert C. Feenstra and Gordon H. Hanson, 1997. "Foreign direct investment and relative wages: Evidence from Mexico's maquiladoras," Journal of International Economics, 42(3-4), 371-393.

[28] J. Michael Finger, Merlinda D. Ingco and Ulrich Reincke, 1996. "The Uruguay Round, Statistics on Tariff Concessions Given and Received " The World Bank.

[29] Gita Gopinath and Brent Neiman. 2014. "Trade Adjustment and Productivity in Large Crises," American Economic Review, 104(3), 793-831.

[30] Maarten Goos, Alan Manning, and Anna Salomons. 2014. "Explaining Job Polarization: Routine-Biased Technological Change and Offshoring," American Economic Review, 104(8), 25092526 . 
[31] Gene M. Grossman and Esteban Rossi-Hansberg, 2008. "Trading Tasks: A Simple Theory of Offshoring," American Economic Review, 98(5), 1978-97.

[32] László Halpern, , Miklós Koren, and Adam Szeidl, 2015. "Imported Inputs and Productivity," American Economic Review, 105(12), 3660-3703.

[33] James Harrigan and Ariell Reshef, 2015. "Skill Biased Heterogeneous Firms, Trade Liberalization, and the Skill Premium," Canadian Journal of Economics, 48(3).

[34] Elhanan Helpman, 1984. "A Simple Theory of International Trade with Multinational Corporations," Journal of Political Economy, 92(3), 451-471.

[35] Elhanan Helpman, Oleg Itskhoki and Stephen Redding, 2010. "Inequality and Unemployment in a Global Economy," Econometrica, 78, 1239-1283.

[36] Elhanan Helpman, Oleg Itskhoki, Marc Muendler and Stephen Redding, 2017. "Trade and Inequality: From Theory to Estimation," Review of Economic Studies, 84(1), 357-405.

[37] David Hummels, Rasmus Jørgensen, Jakob R. Munch and Chong Xiang, 2014. "The Wage Effects of Offshoring: Evidence from Danish Matched Worker-Firm Data," American Economic Review, 104(6), 1597-1629.

[38] Miklós Koren, and Márton Czillag, 2017. "Machines and machinists: Importing Skill-biased Technology," manuscript.

[39] Per Krusell and Lee E. Ohanian and Jose-Victor Rios-Rull and Giovanni L. Violante, 2000. "Capital-Skill Complementarity and Inequality: A Macroeconomic Analysis," Econometrica, 68(5), 1029-1054.

[40] James Levinsohn and Amil Petrin, 2003. "Estimating Production Functions Using Inputs to Control for Unobservables," Review of Economic Studies, 70(2), 317-341.

[41] Marc J. Melitz, 2003. "The Impact of Trade on Intra-Industry Reallocations and Aggregate Industry Productivity," Econometrica, 71(6), 1695-1725.

[42] Yue Ma, Heiwai Tang and Yifan Zhang, 2014. "Factor intensity, product switching, and productivity: Evidence from Chinese exporters," Journal of International Economics, 92, 349-362.

[43] Giordano Mion and Linke Zhu, 2013. "Import competition from and offshoring to China: A curse or blessing for firms?," Journal of International Economics, 89(1), 202-215.

[44] Nathan Nunn, 2007. "Relationship-Specificity, Incomplete Contracts, and the Pattern of Trade," Quarterly Journal of Economics, 122(2), 569-600.

[45] Justin R. Pierce and Peter K. Schott, 2009. "A Concordance Between Ten-Digit U.S. Harmonized System Codes and SIC/NAICS Product Classes and Industries, "NBER Working Paper 15548.

[46] John Romalis, 2004. "Factor proportions and the structure of commodity trade," American Economic Review, 94( 1), 67-97.

[47] Daniel Trefler, 1995. "The Case of Missing Trade and Other Mysteries," American Economic Review, 85, 1029-1046.

[48] Peter Schott, 2004. "Across-Product versus Within-Product Specialization in International Trade," Quarterly Journal of Economics 119(2), 647-678.

[49] Eric Verhoogen, 2008. "Trade, Quality Upgrading and Wage Inequality in the Mexican Manufacturing Sector," Quarterly Journal of Economics, 123(2), 489-530.

[50] Jeffrey Wooldridge, 2009. "On estimating firm-level production functions using proxy variables to control for unobservables," Economics Letters,104, 112114.

[51] World Trade Organization, 2013. "International Trade Statistics 2013". 
[52] Stephen Ross Yeaple 2003. "The Role of Skill Endowments in the Structure of U.S. Outward Foreign Direct Investment," The Review of Economics and Statistics, 85(3), 726-734. 


\section{Appendix A: Function $M C_{n}$ and Firm's Optimal Behavior}

\section{A-1 Characterization of the offshoring decision}

Without loss of generality, consider a country- $n$ firm with productivity $\gamma$ that finds it profitable to offshore the range of labor-intensive inputs $\left[z_{a}, z_{b}\right], 0<z_{a}<z_{b}<z_{n-1}$. Again without loss of generality, assume all inputs are being sourced from one country only. The firm's marginal-cost function is in this case

$$
M C_{n}\left(\gamma, z_{a}, z_{b}\right)=\frac{1}{\gamma}\left[\int_{0}^{z_{a}} p_{n n}^{1-\varepsilon}(z) d z+\int_{z_{a}}^{z_{b}} p_{n^{\prime} n}^{1-\varepsilon}(z) d z+\int_{z_{b}}^{1} p_{n n}^{1-\varepsilon}(z) d z\right]^{\frac{1}{1-\varepsilon}}
$$

The first derivative of this function with respect to $z_{a}$ is

$$
\frac{\partial M C_{n}}{\partial z_{a}}=M C_{n}\left[\frac{p_{n n}^{1-\varepsilon}\left(z_{a}\right)-p_{n^{\prime} n}^{1-\varepsilon}\left(z_{a}\right)}{(1-\varepsilon) \gamma^{1-\varepsilon} M C_{n}^{1-\varepsilon}}\right]=M C_{n} A_{n^{\prime} n}>0 .
$$

Extending the offshoring range towards more labor-intensive inputs (that is, decreasing $z_{a}$ ) reduces $M C_{n}$. Moreover, it is easy to show that

$$
\frac{\partial^{2} M C_{n}}{\partial\left(z_{a}\right)^{2}}=M C_{n}\left(A_{n^{\prime} n}^{2}+\frac{\partial A_{n^{\prime} n}}{\partial z_{a}}\right)<0 .
$$

From the discussion of Figure 1, offshoring inputs to the left of $z_{a}$ reduces the firm's marginal cost (and thereby raises its revenue) by even more than offshoring input $z_{a}$. Since offshoring any input is subject to the same cost $P f^{o}$, it must be profitable to offshore any input $z<z_{a}$.

By the same token, if a country- $n$ firm with productivity $\gamma$ finds it profitable to offshore the range of inputs $\left[z_{c}, z_{d}\right], z_{n}<z_{c}<z_{d}<1$, it must be profitable to offshore any input $z>z_{d}$. Thus, the firm's offshoring decision is charaterized by a pair $\left\{z_{n}^{-}(\gamma), z_{n}^{+}(\gamma)\right\}, 0 \leq z_{n}^{-}(\gamma) \leq z_{n-1}$, $z_{n} \leq z_{n}^{+}(\gamma) \leq 1$, such that all $z \leq z_{n}^{-}(\gamma)$ are offshored to labor-abundant countries and all $z \geq z_{n}^{+}(\gamma)$ are offshored to skill-abundant countries. Inputs in the range $\left(z_{n}^{-}(\gamma), z_{n}^{+}(\gamma)\right)$ are instead produced in-house.

\section{A-2 Function $M C_{n}$}

A country- $n$ final-good producer with productivity $\gamma$ that offshores inputs to labor-abundant countries $\left\{1,2, \ldots, n^{-}\right\}, n^{-}<n$, and to skill-abundant countries $\left\{n^{+}, n^{+}+1, \ldots, N\right\}, n^{+}>n$, has marginal-cost function: ${ }^{58}$

$$
\begin{aligned}
& M C_{n}\left(\gamma, z_{n}^{-}, z_{n}^{+}\right)=\frac{1}{\gamma}\left[\sum_{n^{\prime}=1}^{n^{-}-1} \int_{z_{n^{\prime}-1}}^{z_{n^{\prime}}} p_{n^{\prime} n}^{1-\varepsilon}(z) d z+\int_{z_{n^{-}-1}}^{z_{n}^{-}} p_{n^{-} n}^{1-\varepsilon}(z) d z+\right. \\
& \left.+\int_{z_{n}^{-}}^{z_{n}^{+}} p_{n n}^{1-\varepsilon}(z) d z+\int_{z_{n}^{+}}^{z_{n}++1} p_{n^{+} n}^{1-\varepsilon}(z) d z+\sum_{n^{\prime}=n^{+}+1}^{N-1} \int_{z_{n^{\prime}}}^{z_{n^{\prime}+1}} p_{n^{\prime} n}^{1-\varepsilon}(z) d z .\right]^{\frac{1}{1-\varepsilon}} .
\end{aligned}
$$

The terms in the square brackets represent the cost of, from left to right, offshoring the most labor-intensive inputs to the set of most labor-abundant countries; the inputs offshored to the "marginal" labor-abundant country; the inputs produced domestically; the inputs offshored to the "marginal" skill-abundant country; offshoring the most skill-intensive inputs to the set of most skill-abundant countries.

\footnotetext{
${ }^{58}$ The function $M C_{n}$ does not include the fixed costs involved in the offshoring of inputs.
} 
For any $z_{n}^{-}<z_{n-1}$, the derivative of $M C_{n}$ with respect to $z_{n}^{-}$is

$$
\frac{\partial M C_{n}}{\partial z_{n}^{-}}=M C_{n}\left[\frac{p_{n^{\prime} n}^{1-\varepsilon}\left(z_{n}^{-}\right)-p_{n n}^{1-\varepsilon}\left(z_{n}^{-}\right)}{(1-\varepsilon) \gamma^{1-\varepsilon} M C_{n}^{1-\varepsilon}}\right]=M C_{n} B_{n^{-} n}<0,
$$

since $p_{n^{\prime} n}\left(z_{n}^{-}\right)<p_{n n}\left(z_{n}^{-}\right)$for a country- $n$ firm to import from any country $n^{\prime}<n$. (Similarly, one can show $\partial M C_{n} / \partial\left(1-z_{n}^{+}\right)<0$ for any $z_{n}^{+}>z_{n}$.)

It is easy to see that $M C_{n}$ is continuous and differentiable. In particular, at the cutoff points $z_{n^{\prime}}$

$$
\begin{aligned}
\left.\lim _{\varepsilon \rightarrow 0} M C_{n}\right|_{z_{n}^{-}=z_{n^{\prime}}-\varepsilon} & =\left.\lim _{\varepsilon \rightarrow 0} M C_{n}\right|_{z_{n}^{-}=z_{n^{\prime}}+\varepsilon}, \\
\left.\lim _{\varepsilon \rightarrow 0} \frac{\partial M C_{n}}{\partial z_{n}^{-}}\right|_{z_{n}^{-}=z_{n^{\prime}}-\varepsilon} & =\left.\lim _{\varepsilon \rightarrow 0} \frac{\partial M C_{n}}{\partial z_{n}^{-}}\right|_{z_{n}^{-}=z_{n^{\prime}}+\varepsilon}<0 .
\end{aligned}
$$

(Similar results apply to $1-z_{n}^{+}$.)

\section{A-3 Firm's optimal behavior}

\section{A-3.1 First-order conditions}

We define variable profits $\pi_{n} \equiv\left(p_{n}-M C_{n}\right) q_{n}$. Demand for the final good is given by $q_{n}=p_{n}^{-\sigma} D$. The first-order condition with respect to $p_{n}$ yields the constant mark-up pricing rule $p_{n}(\gamma)=$ $\frac{\sigma}{\sigma-1} M C_{n}(\gamma)$. The first-order conditions with respect to $z_{n}^{-}<z_{n-1}$ and $\left(1-z_{n}^{+}\right), z_{n}^{+}>z_{n}$ are

$$
\begin{aligned}
\frac{\partial \Pi_{n}}{\partial z_{n}^{-}} & =\frac{\partial \pi_{n}}{\partial z_{n}^{-}}-P f^{o}=-\frac{\partial M C_{n}}{\partial z_{n}^{-}} p_{n}^{-\sigma} D-P f^{o} \leq 0 \\
\frac{\partial \Pi_{n}}{\partial\left(1-z_{n}^{+}\right)} & =\frac{\partial \pi_{n}}{\partial\left(1-z_{n}^{+}\right)}-P f^{o}=-\frac{\partial M C_{n}}{\partial\left(1-z_{n}^{+}\right)} p_{n}^{-\sigma} D-P f^{o} \leq 0,
\end{aligned}
$$

with $\pi_{n}$ increasing and concave in $z_{n}^{-}$and $\left(1-z_{n}^{+}\right) .{ }^{59}$ Imposing strict equality on equation (A-8) and manipulating it,

$$
\frac{\partial \Pi_{n}}{\partial z_{n}^{-}}=\left(\frac{\sigma}{\sigma-1}\right)^{-\sigma} \frac{\left[p_{n^{-} n}^{1-\varepsilon}\left(z_{n}^{-}\right)-p_{n n}^{1-\varepsilon}\left(z_{n}^{-}\right)\right]}{(\varepsilon-1) \gamma^{1-\varepsilon} M C_{n}^{\sigma-\varepsilon}} D-P f^{o}=0 .
$$

By the Implicit-function Theorem,

$$
\frac{\partial z_{n}^{-}}{\partial \gamma}=-\frac{(\sigma-1) \gamma^{-1} B_{n^{-} n}}{(1-\sigma)\left(B_{n^{-} n}\right)^{2}+\partial B_{n^{-} n} / \partial z_{n}^{-}}>0
$$

if and only if the denominator $(1-\sigma)\left(B_{n^{-} n}\right)^{2}+\partial B_{n^{-} n} / \partial z_{n}^{-}$is positive. A sufficient condition for this is $\sigma \geq \varepsilon>1$. (A similar result can be obtained for $\partial\left(1-z_{n}^{+}\right) / \partial \gamma$.)

\footnotetext{
${ }^{59}$ The condition $\partial \Pi_{n} / \partial z_{n}^{-}=0$ evaluated at $z_{n}^{-}=0$ implicitly defines the threshold-level $\gamma_{n}^{-}$where country- $n$ firms start to offshore a positive measure of labor-intensive inputs. Similarly, $\partial \Pi_{n} / \partial z_{n}^{+}=0$ evaluated at $z_{n}^{+}=1$ defines $\gamma_{n}^{+}$. Firms with $\gamma<\gamma_{n}^{o}=\min \left(\gamma_{n}^{-}, \gamma_{n}^{+}\right)$source all inputs domestically. Other things equal, if $\tau_{n^{\prime} n}$ is higher for $n^{\prime}<n$ than for $n^{\prime}>n$, then $\gamma_{n}^{-}>\gamma_{n}^{+}$: firms require a lower productivity level to import from skill-abundant countries than from labor-abundant countries.
} 


\section{A-4 Second-order condition}

The second partial derivatives of the firm's profit function, evaluated at $p_{n}=\frac{\sigma}{\sigma-1} M C_{n}$, are: ${ }^{60}$

$$
\begin{gathered}
\frac{\partial^{2} \Pi_{n}}{\partial p_{n}^{2}}=-\sigma\left(\frac{\sigma}{\sigma-1}\right)^{-\sigma-2} M C_{n}^{-\sigma-1} D<0, \\
\frac{\partial^{2} \Pi_{n}}{\partial\left(z_{n}^{-}\right)^{2}}=-\left(\frac{\sigma}{\sigma-1}\right)^{-\sigma} M C_{n}^{1-\sigma}\left(B_{n^{-} n}^{2}+\frac{\partial B_{n^{-} n}}{\partial z_{n}^{-}}\right) D<0, \\
\frac{\partial^{2} \Pi_{n}}{\partial\left(1-z_{n}^{+}\right)^{2}}=-\left(\frac{\sigma}{\sigma-1}\right)^{-\sigma} M C_{n}^{1-\sigma}\left[B_{n^{+} n}^{2}+\frac{\partial B_{n^{+} n}}{\partial\left(1-z_{n}^{+}\right)}\right] D<0, \\
\frac{\partial^{2} \Pi_{n}}{\partial p_{n} \partial z_{n}^{-}}=\sigma\left(\frac{\sigma}{\sigma-1}\right)^{-\sigma-1} M C_{n}^{-\sigma} B_{n^{-} n} D<0, \\
\frac{\partial^{2} \Pi_{n}}{\partial p_{n} \partial\left(1-z_{n}^{+}\right)}=\sigma\left(\frac{\sigma}{\sigma-1}\right)^{-\sigma-1} M C_{n}^{-\sigma} B_{n^{+}{ }_{n} D<0,} \\
\frac{\partial^{2} \Pi_{n}}{\partial z_{n}^{-} \partial\left(1-z_{n}^{+}\right)}=\left(\frac{\sigma}{\sigma-1}\right)^{-\sigma} M C_{n}^{1-\sigma} B_{n^{-}{ }_{n} B_{n^{+} n} D>0 .}
\end{gathered}
$$

The Hessian matrix of the profit function is

$$
H=\left[\begin{array}{ccc}
\frac{\partial^{2} \Pi_{n}}{\partial p_{n}^{2}} & \frac{\partial^{2} \Pi_{n}}{\partial p_{n} \partial z_{n}^{-}} & \frac{\partial^{2} \Pi_{n}}{\partial p_{n} \partial\left(1-z_{n}^{+}\right)} \\
\frac{\partial^{2} \Pi_{n}}{\partial z_{n}^{-} \partial p_{n}} & \frac{\partial^{2} \Pi_{n}}{\partial\left(z_{n}^{-}\right)^{2}} & \frac{\partial^{2} \Pi_{n}}{\partial z_{n}^{-} \partial\left(1-z_{n}^{+}\right)} \\
\frac{\partial^{2} \Pi_{n}}{\partial\left(1-z_{n}^{+}\right) \partial p_{n}} & \frac{\partial^{2} \Pi_{n}}{\partial\left(1-z_{n}^{+}\right) \partial z_{n}^{-}} & \frac{\partial^{2} \Pi_{n}}{\partial\left(1-z_{n}^{+}\right)^{2}}
\end{array}\right] .
$$

It is easy to see that $\partial^{2} \Pi_{n} / \partial p_{n}^{2}<0$;

$$
\begin{aligned}
& \frac{\partial^{2} \Pi_{n}}{\partial p_{n}^{2}} \frac{\partial^{2} \Pi_{n}}{\partial\left(z_{n}^{-}\right)^{2}}-\left(\frac{\partial^{2} \Pi_{n}}{\partial p_{n} \partial z_{n}^{-}}\right)^{2}= \\
= & \sigma\left(\frac{\sigma}{\sigma-1}\right)^{-2(\sigma+1)} M C_{n}^{-2 \sigma}\left[(1-\sigma)\left(B_{n^{-} n}\right)^{2}+\frac{\partial B_{n^{-} n}}{\partial z_{n}^{-}}\right] D^{2}>0
\end{aligned}
$$

for $\sigma \geq \varepsilon>1$; denoting the determinant of the Hessian matrix with $|H|$, and after some tedious algebra,

$$
\begin{aligned}
& |H|=\sigma\left(\frac{\sigma}{\sigma-1}\right)^{-3 \sigma-2} M C_{n}^{1-3 \sigma} \times \\
& \times\left[(\sigma-1)\left[B_{n^{-} n}^{2} \frac{\partial B_{n^{+} n}}{\partial\left(1-z_{n}^{+}\right)}+B_{n^{+} n}^{2} \frac{\partial B_{n^{-} n}}{\partial z_{n}^{-}}\right]+4 \sigma B_{n^{-} n^{2}}^{2} B_{n^{+} n}^{2}-\frac{\partial B_{n^{-} n}}{\partial z_{n}^{-}} \frac{\partial B_{n^{+} n}}{\partial\left(1-z_{n}^{+}\right)}\right] D^{3}<0,
\end{aligned}
$$

\footnotetext{
${ }^{60}$ The first-order condition with respect to $p_{n}$ does not depend on the offshoring decision directly, but only to the extent that $M C_{n}$ depends on $z_{n}^{-}$and $1-z_{n}^{+}$.
} 
as the term $-\frac{\partial B_{n}-n}{\partial z_{n}^{-}} \frac{\partial B_{n}+n}{\partial\left(1-z_{n}^{+}\right)}$is negative and one order of magnitude larger than the other terms. Thus, the Hessian is negative definite and the profit function is therefore strictly concave. ${ }^{61}$ Thus, the first-order conditions identify a global maximum.

\section{A-5 Changes in Variable Offshoring Costs}

\section{A-5.1 Changes in the Marginal Country's Offshoring Cost}

Applying the Implicit-function Theorem to the first-order condition $\partial \Pi / \partial z_{n}^{-}=0$,

$$
\frac{\partial z_{n}^{-}}{\partial \tau_{n^{-} n}}=-\frac{(1-\sigma) M C_{n}^{-\sigma} B_{n^{-} n}\left(\partial M C_{n} / \partial \tau_{n^{\prime} n}\right)+M C_{n}^{1-\sigma}\left(\partial B_{n^{-} n} / \partial \tau_{n^{-} n}\right)}{M C_{n}^{1-\sigma}\left[(1-\sigma)\left(B_{n^{-} n}\right)^{2}+\partial B_{n^{-} n} / \partial z_{n}^{-}\right]}<0,
$$

since $\partial M C_{n} / \partial \tau_{n^{-} n}, \partial B_{n^{-} n} / \partial \tau_{n^{-} n}>0$.

\section{A-5.2 Changes in Variable Offshoring Costs Across All Countries}

Assume $\tau_{n^{\prime} n}=\tau$ for all $n^{\prime}$. In this case, $\partial z_{n}^{-} / \partial \tau<0$ for $z_{n}^{-}>0$ and

$$
\begin{aligned}
\left.\frac{\partial z_{n}^{-}}{\partial \tau}\right|_{z_{n}^{-}=0} & =-\frac{\partial B_{n^{-} n} / \partial \tau}{\left[(1-\sigma)\left(B_{n^{-} n}\right)^{2}+\partial B_{n^{-} n} / \partial z_{n}^{-}\right]}= \\
& =-\frac{\tau^{-1} \gamma^{\varepsilon-1} p_{1 n}^{1-\varepsilon}(0) / M C_{n}^{1-\varepsilon}}{(1-\sigma)\left(B_{n^{-} n}\right)^{2}+\partial B_{n^{-} n} / \partial z_{n}^{-}} \simeq 0 .
\end{aligned}
$$

\footnotetext{
the cutoff points $z_{n, n+1}$. This is due to the second derivative of $M C_{n}$ not being defined at these points $z_{n^{\prime}}$ :

$$
\begin{aligned}
& \frac{\partial^{2} M C_{n}}{\partial\left(z_{n}^{-}\right)^{2}}=M C_{n}\left(B_{n^{-n}}^{2}+\frac{\partial B_{n^{-} n}}{\partial z_{n}^{-}}\right)>0, \\
&\left.\lim _{\varepsilon \rightarrow 0} \frac{\partial^{2} M C_{n}}{\partial\left(z_{n}^{-}\right)^{2}}\right|_{z_{n}^{-}=z_{n^{\prime}-\varepsilon}}>\left.\lim _{\varepsilon \rightarrow 0} \frac{\partial^{2} M C_{n}}{\partial\left(z_{n}^{-}\right)^{2}}\right|_{z_{n}^{-}=z_{n^{\prime}+\varepsilon}}>0 .
\end{aligned}
$$
}

${ }^{61}$ The only (minor) caveat to this analysis is that, although the profit function is continuous and first-order differentiable, its second derivatives with respect to the offshoring margins $z_{n}^{-}$and $1-z_{n}^{+}$are not well defined at

However, the profit function is concave in the neighborhood of each cutoff point. 


\section{Appendix Tables}

\begin{tabular}{|c|c|c|c|c|c|}
\hline Variable & Mean & Std. Dev. & 5th Pct. & 95th Pct. & Obs. \\
\hline Skill intensity $f, t$ & 1.18 & 4.50 & 0.14 & 3.50 & 646,920 \\
\hline Employees $_{f, t}$ & 53.51 & 336.58 & 3.00 & 174.00 & 646,920 \\
\hline$(\log ) \operatorname{TFP}_{f, t}$ & 3.83 & 0.46 & 3.05 & 4.56 & 646,920 \\
\hline (log) Capital/labor $f, t$ & 3.25 & 0.99 & 1.52 & 4.83 & 646,920 \\
\hline $\operatorname{Imports}_{f, t}$ (in 1000 euros) & 1,908 & 24,403 & 0.0 & 4,047 & 646,920 \\
\hline $\operatorname{Exports}_{f, t}$ (in 1000 euros) & 1,375 & 26,606 & 0.0 & 3,030 & 646,920 \\
\hline Number of products imported f $_{f, t}$ (all origins) & 5.36 & 16.72 & 0.00 & 29.00 & 646,920 \\
\hline Number of products imported from skill-abundant countries $f, t$ & 10.07 & 19.02 & 1.00 & 39.00 & 182,239 \\
\hline Number of products imported from labor-abundant $\operatorname{countries}_{f, t}$ & 6.11 & 11.59 & 1.00 & 24.00 & 96,039 \\
\hline Number of countries per firm-product $f, p, t$ (all origins) & 1.74 & 1.11 & 1.00 & 3.74 & 224,039 \\
\hline Number of countries per firm-product $f, p, t$ (skill-abundant countries) & 1.21 & 0.39 & 1.00 & 2.00 & 182,239 \\
\hline Number of countries per firm-product $f, p, t$ (labor-abundant countries) & 1.35 & 0.96 & 1.00 & 2.61 & 96,039 \\
\hline
\end{tabular}

Table A-1: Summary Statistics Summary statistics for the baseline estimating sample. 95\% cutoff refers to the group of countries with a level secondary schooling less than $95 \%$ of that of France. See Table A-4 for the list of countries.

Table A-2: Production function output elasticity estimates by 2-digit sector (Levinsohn-Petrin)

\begin{tabular}{|c|c|c|c|c|c|c|c|}
\hline 2-digit code & Title & Unskilled labor & s.e. & Skilled labor & s.e. & Capital & s.e. \\
\hline 10 & Food products & 0.38 & 0.00 & 0.31 & 0.00 & 0.23 & 0.02 \\
\hline 11 & Beverages & 0.31 & 0.02 & 0.41 & 0.02 & 0.25 & 0.05 \\
\hline 13 & Textiles & 0.36 & 0.01 & 0.35 & 0.01 & 0.18 & 0.01 \\
\hline 14 & Wearing apparel & 0.31 & 0.01 & 0.40 & 0.01 & 0.31 & 0.03 \\
\hline 15 & Leather and related products & 0.42 & 0.01 & 0.33 & 0.02 & 0.25 & 0.04 \\
\hline 16 & Wood and products of wood and cork & 0.42 & 0.01 & 0.29 & 0.01 & 0.17 & 0.02 \\
\hline 17 & Paper and paper products & 0.35 & 0.01 & 0.32 & 0.01 & 0.19 & 0.03 \\
\hline 18 & Printing and reproduction of recorded media & 0.34 & 0.01 & 0.39 & 0.01 & 0.15 & 0.01 \\
\hline 20 & Chemicals and chemical products & 0.19 & 0.01 & 0.53 & 0.01 & 0.20 & 0.02 \\
\hline 21 & Basic pharmaceutical products & 0.10 & 0.02 & 0.69 & 0.03 & 0.16 & 0.05 \\
\hline 22 & Rubber and plastic products & 0.33 & 0.01 & 0.35 & 0.01 & 0.22 & 0.01 \\
\hline 23 & Other non-metallic mineral products & 0.37 & 0.01 & 0.31 & 0.01 & 0.22 & 0.03 \\
\hline 24 & Basic metals & 0.37 & 0.02 & 0.37 & 0.01 & 0.22 & 0.05 \\
\hline 25 & Fabricated metal products & 0.40 & 0.00 & 0.32 & 0.00 & 0.20 & 0.01 \\
\hline 26 & Computers, electronic and optical products & 0.17 & 0.01 & 0.53 & 0.01 & 0.19 & 0.05 \\
\hline 27 & Electrical equipment & 0.27 & 0.01 & 0.45 & 0.01 & 0.19 & 0.01 \\
\hline 28 & Machinery and equipment n.e.c. & 0.26 & 0.00 & 0.47 & 0.01 & 0.18 & 0.02 \\
\hline 29 & Motor vehicles, trailers and semi-trailers & 0.38 & 0.01 & 0.36 & 0.02 & 0.18 & 0.02 \\
\hline 30 & Other transport equipment & 0.39 & 0.02 & 0.45 & 0.02 & 0.17 & 0.03 \\
\hline 31 & Furniture & 0.40 & 0.01 & 0.29 & 0.01 & 0.22 & 0.02 \\
\hline 32 & Other manufacturing & 0.23 & 0.01 & 0.49 & 0.01 & 0.25 & 0.02 \\
\hline
\end{tabular}


Table A-3: Average annual wages by worker category

\begin{tabular}{ccccccr}
\hline \hline & $\begin{array}{c}\text { Firm owners } \\
\text { receiving a wage }\end{array}$ & $\begin{array}{c}\text { Admin. and commer. } \\
\text { managers }\end{array}$ & $\begin{array}{c}\text { Technicians and } \\
\text { supervisors }\end{array}$ & White Collars & Blue Collars & $\begin{array}{r}\text { Skill } \\
\text { Premium }\end{array}$ \\
\hline 1996 & 34,181 & 36,482 & 20,728 & 13,852 & 13,913 & 1.672 \\
1997 & 34,673 & 37,069 & 20,990 & 14,111 & 14,198 & 1.672 \\
1998 & 35,634 & 37,337 & 21,146 & 14,374 & 14,359 & 1.678 \\
1999 & 37,507 & 38,269 & 21,364 & 14,520 & 14,580 & 1.702 \\
2000 & 39,377 & 39,474 & 21,717 & 14,672 & 14,854 & 1.709 \\
2001 & 52,423 & 40,488 & 21,477 & 14,469 & 15,003 & 1.735 \\
2002 & 59,210 & 41,197 & 21,884 & 14,771 & 15,395 & 1.754 \\
2003 & 59,725 & 41,736 & 22,324 & 15,054 & 15,781 & 1.752 \\
2004 & 62,391 & 42,400 & 22,692 & 15,313 & 16,195 & 1.739 \\
2005 & 65,893 & 43,564 & 23,233 & 15,769 & 16,692 & 1.733 \\
2006 & 69,410 & 44,387 & 23,710 & 16,063 & 16,887 & 1.749 \\
2007 & 75,681 & 45,775 & 24,315 & 16,453 & 17,377 & 1.762 \\
\hline \hline
\end{tabular}

Table A-4: Country List

The table shows the list of labor-abundant and skill-abundant countries and their skill endowments (years of second. schooling) relative to those of France.

\begin{tabular}{|c|c|c|c|c|c|c|c|c|}
\hline & \multicolumn{5}{|c|}{$\begin{array}{l}\text { labor-abundant countries } \\
\text { countries with less than } 95 \text { percent of } \\
\text { secondary schooling relative to France }\end{array}$} & \multicolumn{3}{|c|}{$\begin{array}{c}\text { skill-abundant countries } \\
\text { countries with more than } 95 \text { percent of } \\
\text { secondary schooling relative to France }\end{array}$} \\
\hline 1. & $\mathrm{AE}$ & .7309386 & 55. & $\mathrm{LS}$ & .151501 & & $\mathrm{AM}$ & 1.059997 \\
\hline 2. & $\mathrm{AF}$ & .1314128 & 56. & LV & .9137048 & 2. & $\mathrm{AT}$ & 1.110806 \\
\hline 3. & AL & .5920595 & 57. & LY & .4295662 & 3. & $\mathrm{AU}$ & 1.119385 \\
\hline 4. & $\mathrm{AR}$ & .4808482 & 58. & MA & .3117399 & 4. & $\mathrm{BE}$ & .8608547 \\
\hline 5. & $\mathrm{BB}$ & .7165515 & 59. & ML & .0475906 & 5. & $\mathrm{CA}$ & 1.046816 \\
\hline 6. & $\mathrm{BD}$ & .2870677 & 60. & $\mathrm{MO}$ & .4659802 & 6. & $\mathrm{CH}$ & .9515527 \\
\hline 7. & $\mathrm{BG}$ & .3955432 & 61. & MR & .1341498 & 7. & $\mathrm{DE}$ & 1.55325 \\
\hline 8. & $\mathrm{BH}$ & .7117896 & 62. & MT & .7728956 & 8. & DK & .6690449 \\
\hline 9. & BI & .0553131 & 63. & MU & .477919 & 9. & $\mathrm{EE}$ & 1.099028 \\
\hline 10. & BJ & .2138808 & 64. & MV & .179614 & 10. & ES & .7981551 \\
\hline 11. & $\mathrm{BO}$ & .491981 & 65. & MW & .0882907 & 11. & FI & .6404628 \\
\hline 12. & $\mathrm{BR}$ & .389559 & 66. & MX & .5076872 & 12. & GB & .6055459 \\
\hline 13. & BW & .5623448 & 67. & MY & .7527282 & 13. & GR & .677312 \\
\hline 14. & BZ & .3414025 & 68. & MZ & .0240641 & 14. & IE & .7481001 \\
\hline 15. & $\mathrm{CF}$ & .1953181 & 69. & NA & .2750658 & 15. & IL & 1.031732 \\
\hline 16. & CG & .4966786 & 70. & $\mathrm{NE}$ & .0549424 & 16. & IT & .8699554 \\
\hline 17. & CI & .228359 & 71. & NI & .3261572 & 17. & KG & 1.106695 \\
\hline 18. & $\mathrm{CL}$ & .7260661 & 72. & NP & .1958776 & 18. & $\mathrm{KR}$ & .9750521 \\
\hline 19. & $\mathrm{CM}$ & .2887197 & 73. & $\mathrm{NZ}$ & .7704451 & 19. & $\mathrm{KZ}$ & 1.252003 \\
\hline 20. & $\mathrm{CN}$ & .4153519 & 74. & PA & .6558818 & 20. & LT & .9786831 \\
\hline 21. & $\mathrm{CO}$ & .5057312 & 75 . & $\mathrm{PE}$ & .5844324 & 21. & MN & 1.011952 \\
\hline 22. & $\mathrm{CR}$ & .4717965 & 76. & PG & .1363502 & 22. & NL & .9803112 \\
\hline 23. & $\mathrm{CU}$ & .8939063 & 77 . & $\mathrm{PH}$ & .4554131 & 23. & $\mathrm{NO}$ & 1.028973 \\
\hline 24 . & $\mathrm{CY}$ & .7657192 & 78. & PK & .3693197 & 24 . & $\mathrm{PT}$ & .4179747 \\
\hline 25 . & $\mathrm{CZ}$ & .7329774 & 79. & PL & .4577564 & 25 . & RU & 1.071076 \\
\hline 26. & DO & .436601 & 80. & PY & .3851919 & 26. & $\mathrm{SE}$ & 1.058099 \\
\hline 27 . & DZ & .5304362 & 81. & QA & .5798559 & 27 . & $\mathrm{TJ}$ & 1.313763 \\
\hline 28. & $\mathrm{EC}$ & .4662719 & 82. & RO & .6413823 & 28. & UA & 1.021971 \\
\hline 29. & EG & .4232834 & 83. & RW & .0678145 & 29. & US & 1.225094 \\
\hline 30. & FJ & .485014 & 84. & $\mathrm{SA}$ & .5231656 & & & \\
\hline 31. & GA & .5109327 & 85. & SD & .1494433 & & & \\
\hline 32. & GH & .6138528 & 86. & SG & .5702106 & & & \\
\hline 33. & GM & .1836017 & 87. & SI & .8483534 & & & \\
\hline 34. & GT & .1865626 & 88. & SK & .5483096 & & & \\
\hline 35. & GY & .6310829 & 89. & $\mathrm{SL}$ & .1401012 & & & \\
\hline 36. & HK & .8751844 & 90. & $\mathrm{SN}$ & .1650027 & & & \\
\hline 37. & $\mathrm{HN}$ & .2902249 & 91. & SV & .2824409 & & & \\
\hline 38. & HR & .4625853 & 92. & SY & .2357891 & & & \\
\hline 39. & $\mathrm{HT}$ & .3092275 & 93. & $\mathrm{SZ}$ & .349172 & & & \\
\hline 40. & $\mathrm{HU}$ & .6619022 & 94. & TG & .3153953 & & & \\
\hline 41. & ID & .2758581 & 95. & $\mathrm{TH}$ & .2102691 & & & \\
\hline 42. & IN & .2574803 & 96. & $\mathrm{TN}$ & .3826243 & & & \\
\hline 43. & IQ & .3585498 & 97. & TO & .6930901 & & & \\
\hline 44. & IR & .5378078 & 98. & $\mathrm{TR}$ & .3407429 & & & \\
\hline 45. & IS & .7461535 & 99. & TT & .4641713 & & & \\
\hline 46. & $\mathrm{JM}$ & .706382 & 100. & $\mathrm{TW}$ & .8451896 & & & \\
\hline 47. & $\mathrm{JO}$ & .6961749 & 101. & $\mathrm{TZ}$ & .0639823 & & & \\
\hline 48. & JP & .9183093 & 102. & UG & .1276823 & & & \\
\hline 49. & $\mathrm{KE}$ & .2151037 & 103. & UY & .4867847 & & & \\
\hline 50. & $\mathrm{KH}$ & .2059049 & 104. & VE & .2877671 & & & \\
\hline 51. & KW & .6705643 & 105. & VN & .2042301 & & & \\
\hline 52. & LA & .2095689 & 106. & YE & .0909453 & & & \\
\hline 53. & LK & .6956804 & 107. & $\mathrm{ZA}$ & .4810084 & & & \\
\hline \multirow[t]{2}{*}{54.} & LR & .234529 & 108. & $\mathrm{ZM}$ & .2556604 & & & \\
\hline & & & 109. & ZW & .4746646 & & & \\
\hline
\end{tabular}




\begin{tabular}{|c|c|c|c|c|c|c|c|c|}
\hline & \multicolumn{5}{|c|}{$\begin{array}{ll} & \text { dependent variable is standard deviation of } \\
\end{array}$} & $\begin{array}{l}\text { intensity } f, c \\
\text { orts from skill }\end{array}$ & \multicolumn{2}{|c|}{$\begin{array}{l}\text { country skill-abundance } f \\
\text { abundant countries }\end{array}$} \\
\hline & $(1)$ & $(2)$ & (3) & $(4)$ & (5) & $(6)$ & $(7)$ & $(8)$ \\
\hline $\log (\mathbf{T F P})_{f}$ & $\begin{array}{c}\mathbf{0 . 0 1 7 9 * * *} \\
(0.000)\end{array}$ & $\begin{array}{c}\mathbf{0 . 0 1 1 1 * * *} \\
(0.001)\end{array}$ & $\begin{array}{c}\mathbf{0 . 0 4 0 7 * * *} \\
(0.011)\end{array}$ & $\begin{array}{c}\mathbf{0 . 0 4 4 4 * * *} \\
(0.011)\end{array}$ & $\begin{array}{c}\mathbf{0 . 0 0 8 3} * * * \\
(0.000)\end{array}$ & $\begin{array}{c}\mathbf{0 . 0 0 5 1 * * *} \\
(0.000)\end{array}$ & $\begin{array}{l}\mathbf{0 . 0 3 1 3} \text { *** } \\
(0.007)\end{array}$ & $\begin{array}{c}\mathbf{0 . 0 1 7 8} * * \\
(0.007)\end{array}$ \\
\hline $\log (\text { employees })_{f}$ & & $\begin{array}{c}0.0034^{* * *} \\
(0.000)\end{array}$ & & $\begin{array}{c}0.0012 \\
(0.005)\end{array}$ & & $\begin{array}{c}0.0035^{* * *} \\
(0.000)\end{array}$ & & $\begin{array}{c}-0.0196^{* * *} \\
(0.003)\end{array}$ \\
\hline $\log (\text { capital/labor })_{f}$ & & $\begin{array}{c}-0.0012^{* * *} \\
(0.000)\end{array}$ & & $\begin{array}{r}-0.0088 \\
(0.006)\end{array}$ & & $\begin{array}{c}0.0027^{* * *} \\
(0.000)\end{array}$ & & $\begin{array}{c}-0.0076^{* *} \\
(0.004)\end{array}$ \\
\hline $\log (\text { exports })_{f}$ & & $\begin{array}{c}0.0025^{* * *} \\
(0.000)\end{array}$ & & $\begin{array}{c}-0.0135^{* * *} \\
(0.003)\end{array}$ & & $\begin{array}{c}0.0005^{* * *} \\
(0.000)\end{array}$ & & $\begin{array}{l}-0.0147^{* * *} \\
(0.002)\end{array}$ \\
\hline $\log (\# \text { products })_{f, c}$ & $\begin{array}{c}0.0125^{* * *} \\
(0.000)\end{array}$ & $\begin{array}{c}0.0100^{* * * *} \\
(0.001)\end{array}$ & & & $\begin{array}{c}0.0114^{* * *} \\
(0.000)\end{array}$ & $\begin{array}{c}0.0083^{* * *} \\
(0.001)\end{array}$ & & \\
\hline $\log (\# \text { countries })_{f}$ & & & $\begin{array}{c}0.2628^{* * *} \\
(0.007)\end{array}$ & $\begin{array}{c}0.2763^{* * *} \\
(0.008)\end{array}$ & & & $\begin{array}{c}0.2296^{* * *} \\
(0.007)\end{array}$ & $\begin{array}{c}0.2703^{* * *} \\
(0.009)\end{array}$ \\
\hline Observations & 48,469 & 48,469 & 14,573 & 14,573 & 149,719 & 149,719 & 31,218 & 31,218 \\
\hline R-squared & 0.0794 & 0.1000 & 0.0827 & 0.0839 & 0.0763 & 0.0864 & 0.0575 & 0.0613 \\
\hline Country FE & NO & YES & NO & NO & NO & YES & NO & NO \\
\hline Robust & YES & YES & YES & YES & YES & YES & YES & YES \\
\hline
\end{tabular}

Table A-5: Dispersion of product skill intensity/country skill-abundance and firm-level productivity

The dependent variable is the standard deviation of product-level skill intensity by source country and firm (in columns (1)-(2) and (5)-(6)) and the standard deviation of the source countries' secondary schooling endowments by firm (in columns (3)-(4) and (7)-(8)). In columns (1)-(4) we consider imports from laborabundant countries, while in columns (5)-(8) we consider imports from skill-abundant countries. We define countries with less than 95 percent of the French level of secondary schooling as labor-abundant and the remaining countries as skill abundant. The main explanatory variable of interest is log firm-level productivity averaged over the sample period computed with the Levinsohn-Petrin method $\left(\log (T F P)_{f}\right)$. Other controls are (all at the firm level and in logs): the number of employees, the capital-labor ratio, the value of exports, the total number of products imported from a given country and the number of countries from which a given firm imports. Standard errors are robust to heteroscedasticity. 


\begin{tabular}{|c|c|c|c|c|c|c|c|c|}
\hline \multicolumn{9}{|c|}{ dependent variable is $\log$ (skill intensity $)_{f t}$} \\
\hline & $(1)$ & $(2)$ & $(3)$ & $(4)$ & (5) & (6) & (7) & $(8)$ \\
\hline import status & $0.2754^{* * *}$ & $0.2739 * * *$ & $0.0728^{* * *}$ & $0.0482^{* * *}$ & & & & \\
\hline labor-abundant $\mathbf{c} \cdot f, t$ & $(0.009)$ & $(0.009)$ & $(0.004)$ & $(0.004)$ & & & & \\
\hline $\begin{array}{l}\text { import status } \\
\text { skill-abundant } \mathbf{c} . f+\end{array}$ & $\begin{array}{l}0.0102 \\
(0.006)\end{array}$ & $0.0122^{*}$ & $0.0229^{* * * *}$ & $\begin{array}{l}0.0091^{* * *} \\
(0.003)\end{array}$ & & & & \\
\hline imports/sales & & & & & $0.3208^{* * *}$ & $0.2470^{* * *}$ & $0.3429^{* *}$ & $0.1776^{* *}$ \\
\hline labor-abundant $\mathbf{c} \cdot f, t$ & & & & & $(0.122)$ & $(0.095)$ & $(0.141)$ & $(0.085)$ \\
\hline imports/sales & & & & & -0.0027 & $-0.0082^{*}$ & -0.0220 & $-0.0314^{*}$ \\
\hline skill-abundant c. $f, t$ & & & & & $(0.007)$ & $(0.005)$ & $(0.017)$ & $(0.016)$ \\
\hline $\log (\text { employees })_{f, t}$ & $\begin{array}{l}-0.1542^{* * *} \\
(0.003)\end{array}$ & $\begin{array}{l}-0.1540^{* * *} \\
(0.003)\end{array}$ & $\begin{array}{l}-0.1562^{* * *} \\
(0.005)\end{array}$ & $\begin{array}{l}-0.1892^{* * *} \\
(0.005)\end{array}$ & $\begin{array}{l}-0.1483^{* * *} \\
(0.005)\end{array}$ & $\begin{array}{l}-0.1861^{* * *} \\
(0.005)\end{array}$ & $-0.1893^{* * *}$ & $-0.2289^{* * *}$ \\
\hline $\log (\mathrm{TFP})_{f, t}$ & $0.0485^{* * *}$ & $0.0460^{* * *}$ & $-0.1943^{* * *}$ & $-0.2279 * * *$ & $-0.1902^{* * *}$ & $-0.2267^{* * *}$ & $0.0413^{* * *}$ & $-0.0303^{*}$ \\
\hline & $(0.007)$ & $(0.007)$ & $(0.005)$ & $(0.005)$ & $(0.005)$ & $(0.005)$ & $(0.016)$ & $(0.016)$ \\
\hline $\log (\text { capital/labor })_{f, t}$ & $\begin{array}{l}0.0181^{* * *} \\
(0.003)\end{array}$ & $\begin{array}{l}0.0174^{* * *} \\
(0.003)\end{array}$ & $\begin{array}{l}0.0153^{* * *} \\
(0.004)\end{array}$ & $\begin{array}{l}-0.0304^{* * *} \\
(0.004)\end{array}$ & $\begin{array}{l}0.0203^{* * *} \\
(0.004)\end{array}$ & $\begin{array}{l}-0.0293^{* * *} \\
(0.004)\end{array}$ & $\begin{array}{l}0.0541^{* * *} \\
(0.016)\end{array}$ & $\begin{array}{l}-0.0498^{* * *} \\
(0.016)\end{array}$ \\
\hline export control $_{f, t}$ & $0.1600^{* * *}$ & $0.1595^{* * *}$ & $0.0212^{* * *}$ & $0.0209^{* * *}$ & $0.0234^{* * *}$ & $0.0218^{* * *}$ & 0.0256 & 0.0232 \\
\hline & $(0.006)$ & $(0.006)$ & $(0.003)$ & $(0.003)$ & $(0.004)$ & $(0.003)$ & $(0.016)$ & $(0.016)$ \\
\hline Observations & 646,920 & 646,920 & 646,920 & 646,920 & 646,920 & 646,920 & 55,719 & 55,719 \\
\hline Firms & 104,036 & 104,036 & 104,036 & 104,036 & 104,036 & 104,036 & 12,714 & 12,714 \\
\hline 4-digit sector $\mathrm{FE}$ & YES & YES & NO & NO & NO & NO & NO & NO \\
\hline Firm FE & NO & NO & YES & YES & YES & YES & YES & YES \\
\hline Year FE & NO & YES & NO & YES & NO & YES & NO & YES \\
\hline Cluster & Firm & Firm & Firm & Firm & Firm & Firm & Firm & Firm \\
\hline Sample & All & All & All & All & All & All & Importers & Importers \\
\hline & & & & & & & both & both \\
\hline
\end{tabular}

Table A-6: Skill intensity of domestic production and importing from labor-abundant and skill-abundant countries (extensive and intensive margin), including firm-level controls.

The dependent variable is the firm-level (log) skill intensity of production, defined as the ratio of non-production workers to production workers. We consider countries with less than 95 percent of the French level of secondary schooling as labor abundant and other countries as skill abundant. In columns (1)-(4), the main explanatory variable of interest is a dummy for importing from the set of labor-abundant countries (import status labor-abundant c.) and a dummy for importing from the set of skill-abundant countries (import status skill-abundant c.). In columns (5)-(8), the main explanatory variable of interest is the ratio of imports from set of labor-abundant countries relative to sales (import/sales labor-abundant c.) and the ratio of imports from the set of skill-abundant countries relative to sales (imports/sales skill-abundant c.). Standard errors are clustered at the firm level. 


\begin{tabular}{|c|c|c|c|c|c|c|c|c|}
\hline \multicolumn{9}{|c|}{ dependent variable is $\log (\text { skill intensity })_{f t}$} \\
\hline & (1) & $(2)$ & $(3)$ & $(4)$ & $(5)$ & (6) & (7) & $(8)$ \\
\hline import status & $0.1967^{* * *}$ & $0.1922^{* * *}$ & $0.0571^{* * *}$ & $0.0408^{* * *}$ & & & & \\
\hline labor-abundant $\mathbf{c} \cdot f, t$ & $(0.009)$ & $(0.010)$ & $(0.004)$ & $(0.004)$ & & & & \\
\hline $\begin{array}{l}\text { import status } \\
\text { skill-abundant } \mathbf{c} . f+\end{array}$ & $\begin{array}{l}-0.0324^{* * *} \\
(0.006)\end{array}$ & $\begin{array}{l}-0.0348^{* * *} \\
(0.006)\end{array}$ & $\begin{array}{l}0.0011 \\
0.003)\end{array}$ & $\begin{array}{l}-0.0123^{* * *} \\
(0.003)\end{array}$ & & & & \\
\hline imports/sales & & & & & $0.2994 * *$ & $0.2537 * *$ & $0.3790^{* *}$ & $0.2076^{* *}$ \\
\hline labor-abundant $\mathbf{c} \cdot f, t$ & & & & & $(0.118)$ & $(0.101)$ & $(0.160)$ & $(0.100)$ \\
\hline imports/sales & & & & & $-0.0103^{*}$ & $-0.0160^{* * *}$ & -0.0122 & -0.0209 \\
\hline skill-abundant $\mathbf{c} \cdot f, t$ & & & & & $(0.006)$ & $(0.003)$ & $(0.018)$ & $(0.017)$ \\
\hline import comp.s,t & $-0.0865 * * *$ & $-0.0759 * * *$ & -0.0105 & 0.0043 & -0.0106 & 0.0031 & -0.0316 & 0.0400 \\
\hline & $(0.023)$ & $(0.023)$ & $(0.013)$ & $(0.013)$ & $(0.013)$ & $(0.013)$ & $(0.062)$ & $(0.061)$ \\
\hline Observations & 588,104 & 588,104 & 572,844 & 572,844 & 572,844 & 572,844 & 49,334 & 49,334 \\
\hline Firms & 104,036 & 104,036 & 104,036 & 85,848 & 85,848 & 85,848 & 9,383 & 9,383 \\
\hline 4-digit sector FE & YES & YES & NO & NO & NO & NO & NO & NO \\
\hline Firm FE & NO & NO & YES & YES & YES & YES & YES & YES \\
\hline Year FE & NO & YES & NO & YES & $\mathrm{NO}$ & YES & NO & YES \\
\hline Cluster & Firm & Firm & Firm & Firm & Firm & Firm & Firm & Firm \\
\hline Sample & All & All & All & All & All & All & $\begin{array}{l}\text { Importers } \\
\text { both }\end{array}$ & $\begin{array}{c}\text { Importers } \\
\text { both }\end{array}$ \\
\hline
\end{tabular}

Table A-7: Skill intensity of domestic production and importing from labor-abundant and skill-abundant countries (extensive and intensive margin), controlling for import competition.

The dependent variable is the firm-level (log) skill intensity of production, defined as the ratio of non-production workers to production workers. We consider countries with less than 95 percent of the French level of secondary schooling as labor abundant and other countries as skill abundant. In columns (1)-(4), the main explanatory variable of interest is a dummy for importing from the set of labor-abundant countries (import status labor-abundant c.) and a dummy for importing from the set of skill-abundant countries (import status skill-abundant c.). In columns (5)-(8), the main explanatory variable of interest is the ratio of imports from set of labor-abundant countries relative to sales (import/sales labor-abundant c.) and the ratio of imports from the set of skill-abundant countries relative to sales (imports/sales skill-abundant c.). Import comp. measures import competition at the 4-digit-sector-year level and is computed as Imports/(Sales-Exports+Imports) at the 4-digit NAF level. Standard errors are clustered at the firm level. 


\begin{tabular}{llllc}
\hline \hline \multicolumn{4}{c}{ dependent variable is $\log (\text { skill intensity) })_{f t}$} \\
\hline & \multicolumn{1}{c}{$(1)$} & $(2)$ & $(3)$ & $(4)$ \\
\hline import status & $0.194^{* * *}$ & $0.029^{* * *}$ & & \\
labor-abundant $\mathbf{c} \cdot f, t$ & $(0.009)$ & $(0.004)$ & & \\
import status & $-0.034^{* * *}$ & $-0.013^{* * *}$ & & \\
skill-abundant c. $f, t$ & $(0.006)$ & $(0.003)$ & & \\
imports/sales & & & $0.195^{* *}$ & $0.164^{* *}$ \\
labor-abundant c. $f, t$ & & & $(0.077)$ & $(0.080)$ \\
imports/sales & & & -0.0079 & -0.0133 \\
skill-abundant c. $f, t$ & & & $(0.005)$ & $(0.017)$ \\
\hline Observations & 646,920 & 646,920 & 646,920 & 55,719 \\
Firms & 104,036 & 104,036 & 104,036 & 12,714 \\
4-digit sector-year FE & YES & YES & YES & YES \\
Firm FE & NO & YES & YES & YES \\
Cluster & Firm & Firm & Firm & Firm \\
Sample & All & All & All & Importers \\
& & & & both \\
\hline \hline
\end{tabular}

Table A-8: Skill intensity of domestic production and importing from labor-abundant and skillabundant countries (extensive and intensive margin) controlling for sector-year fixed effects.

The dependent variable is the firm-level $(\log )$ skill intensity of production, defined as the ratio of non-production workers to production workers. We consider countries with less than 95 percent of the French level of secondary schooling as labor abundant and other countries as skill abundant. In columns (1)-(2), the main explanatory variable of interest is a dummy for importing from the set of labor-abundant countries (import status laborabundant c.) and a dummy for importing from the set of skill-abundant countries (import status skill-abundant c.). In columns (3)-(4), the main explanatory variable of interest is the ratio of imports from set of labor-abundant countries relative to sales (import/sales labor-abundant c.) and the ratio of imports from the set of skill-abundant countries relative to sales (imports/sales skill-abundant c.). Standard errors are clustered at the firm level. 


\begin{tabular}{|c|c|c|c|c|}
\hline & \multicolumn{4}{|c|}{ dependent variable } \\
\hline & $\Delta \log (\text { export supply })_{n, p, t}$ & $\log ($ impor & are) $f, p, n, t$ & \\
\hline skill intensity $_{p}$ & $\begin{array}{r}0.315^{* * *} \\
(0.046)\end{array}$ & & & \\
\hline skill intensity $_{p}{ }^{*}$ first year $_{f}$ & & $\begin{array}{r}0.375^{* * *} \\
(0.125)\end{array}$ & $\begin{array}{r}0.274^{* * *} \\
(0.097)\end{array}$ & $\begin{array}{r}0.250^{* * *} \\
(0.096)\end{array}$ \\
\hline Country FE & YES & $\mathrm{NO}$ & $\mathrm{NO}$ & YES \\
\hline Year FE & YES & YES & YES & YES \\
\hline Firm FE & & $\mathrm{NO}$ & YES & YES \\
\hline Product FE & & YES & YES & YES \\
\hline Cluster & Product & Product & Product & Product \\
\hline
\end{tabular}

Table A-9: IV shocks from labor-abundant countries and product characteristics.

Observations are labor-abundant countries (column (1)) and importers from labor-abundant countries (columns (2)- (4)). The dependent variable in column (1) is the growth rate of export supply of country $n$ for product $p$ in year $t$. The dependent variable in columns (2)-(4) is the log import share of product $p$ by firm $f$ from country $n$ in year $t$. The variable of interest in column (1) is the skill intensity of product $p$ and in columns (2)-(4) the interaction between skill intensity of product $p$ and a dummy for the first period that firm $f$ is in the sample. 